\title{
Business Dynamics Statistics of High Tech Industries
}

by

\author{
Nathan Goldschlag* \\ U.S. Census Bureau
}

\author{
Javier Miranda $†$ \\ U.S. Census Bureau
}

CES 16-55

December, 2016

The research program of the Center for Economic Studies (CES) produces a wide range of economic analyses to improve the statistical programs of the U.S. Census Bureau. Many of these analyses take the form of CES research papers. The papers have not undergone the review accorded Census Bureau publications and no endorsement should be inferred. Any opinions and conclusions expressed herein are those of the author(s) and do not necessarily represent the views of the U.S. Census Bureau. All results have been reviewed to ensure that no confidential information is disclosed. Republication in whole or part must be cleared with the authors.

To obtain information about the series, see www.census.gov/ces or contact J. David Brown, Editor, Discussion Papers, U.S. Census Bureau, Center for Economic Studies 5K034A, 4600 Silver Hill Road, Washington, DC 20233, CES.Papers.List@census.gov. To subscribe to the series, please click here. 


\begin{abstract}
Modern market economies are characterized by the reallocation of resources from less productive, less valuable activities to more productive, more valuable ones. Businesses in the High Technology sector play a particularly important role in this reallocation by introducing new products and services that impact the entire economy. Tracking the performance of this sector is therefore of primary importance, especially in light of recent evidence that suggests a slowdown in business dynamism in High Tech industries. The Census Bureau produces the Business Dynamics Statistics (BDS), a suite of data products that track job creation, job destruction, startups, and exits by firm and establishment characteristics including sector, firm age, and firm size. In this paper we describe the methodologies used to produce a new extension to the BDS focused on businesses in High Technology industries.
\end{abstract}

\footnotetext{
${ }^{*}$ Goldschlag, Center for Economic Studies, U.S. Census Bureau; † Miranda, Center for Administrative Records Research and Applications, U.S. Census Bureau. We thank Emin Dinlersoz, John Haltiwanger, Lars Vilhuber and participants at the Center for Economic Studies Seminar Series for helpful comments. All opinions and views expressed are those of the authors and do not represent those of the U.S. Census Bureau. All results have been reviewed to ensure that no confidential information is disclosed.
} 


\section{INTRODUCTION}

Modern market economies are characterized by the reallocation of resources from less productive, less valuable activities to more productive more valuable ones. Businesses that innovate grow and replace those that do not (Schumpeter 1942). The innovations that underlie this reallocation are ultimately responsible for increased productivity growth and increasing standards of living. Businesses in the High Tech sector play a particularly important role in this regard, as they bring about new products and services that fuel this reallocation. Not surprisingly, developing a deeper understanding of these businesses, their inception, early life cycle dynamics, and constraints to growth are the focus of intense attention (Stoneman and Battisti 2010, Acemoglu et al. 2013, Criscuolo et al 2015, Decker et al. 2016a, 2016b). However, our understanding about the dynamics of innovative firms is very limited. One reason for this is that, until recently, we did not have longitudinal datasets of establishments and firms covering the U.S. economy. The development and introduction of the U.S. Census Bureau's Longitudinal Business Database (LBD) changes that. The LBD tracks all establishments and firms with paid employees starting in 1976 and is updated annually (see Jarmin and Miranda 2002 for details). The most recent update includes the 2014 data. The LBD, however, is a confidential micro dataset only accessible to Census Bureau employees and researchers with an approved need to know and therefore access to the data is necessarily limited. In this paper, we describe the use of the confidential microdata in the LBD to create a series of public use fully accessible products describing the dynamics of High Technology firms and establishments. This effort is consistent with the goals of the Census Bureau to produce up-to-date economic and social measures to advance informed decision-making in business and society through the development of public use tabulations while protecting the confidentiality of the data (Jarmin, Louis, and Miranda 2014).

The Business Dynamics Statistics (BDS) program furthers this goal by developing a data product that directly measures the characteristics and dynamics of High Tech businesses. The existing BDS tabulations, built upon the LBD, contain information on the number of firms and establishments, firm openings and closings, and job creation and destruction by relevant firm characteristics including firm age, size, state, MSA, and sector. However, identifying High Tech businesses in the LBD is not a trivial exercise. In this 
paper, we review the existing methodologies used to identify High Tech industries, paying special attention to their potential application and use in BDS data products. These methodologies rely on the identification of inputs and outputs of the innovation process across detailed industries such as R\&D investments, proportion of STEM workers ${ }^{2}$, or the technological content of the products. Currently, the BDS statistics are updated annually. A critical element in the evaluation of these methodologies is the ease with which they can be updated and replicated. Relevant factors in this regard include the timelines and coverage of the underlying data that the methodology employs. In some cases, third party data is used over which the Census Bureau has little control. An equally important consideration when choosing a methodology for identifying High Tech businesses is that it produce stable indicators. A methodology that identifies a volatile set of industries is of little use. Finally, an important requirement is that the methodology be flexible enough to identify High Tech industries across the entire economy since it is increasingly the case that industries outside of manufacturing can reasonably be considered to be High Tech.

We find considerable differences in the list of High Tech industries identified by different methodologies. Output-based and R\&D-based methodologies almost exclusively identify manufacturing industries due to data limitations. Ad hoc extensions to the methodology attempt to compensate for this inherent limitation but yield a very broad listing of industries outside of manufacturing so that their value is questionable. Moreover, these methodologies are relatively hard to replicate and maintain. Input based methods, on the other hand, are relatively easy to maintain and replicate given existing and ongoing survey collections. Amongst these methodologies, the one based on occupation data (what workers do) is the most promising. The availability of occupation data across all industries makes it possible to identify a list of High Tech industries that span all sectors, including information and services industries, using a consistent framework. Despite the very different methodologies and their resulting listings, there is nevertheless significant overlap in the core set of High Tech industries that emerge particularly in the manufacturing sector. Comparing measures of business dynamism derived from the alternative High Tech definitions shows similar overall patterns in the manufacturing

2 Workers in occupations related to Science, Technology, Engineering, and Math (STEM). For examples of such occupations see the Bureau of Labor Statistic's Standard Occupation Classification system Detailed 2010 SOC occupations included in STEM (http://www.bls.gov/soc/ accessed 10/18/2016). 
component of High Tech. Consistent with previous findings in the literature, we find overall declines in business dynamism after 2000. We find High Tech intensity is directly related to the magnitude of the decline. The more intensely-High Tech industries exhibit declines in dynamism that are $20 \%$ greater than those experienced by the less intensely-High Tech industries.

Based on concerns about coverage, stability, interpretation, and replicability, we define High Tech industries based on the union of industries with the highest proportion of STEM employment in 2005, 2012, and 2014. ${ }^{3}$ Using this classification, we compute the Business Dynamics Statistics of High Tech industries (BDS-HT). These data capture flows of firms, establishments, and employment for High Tech and non-High Tech industries. High Tech industries make up a relatively small portion of the economy-about $4 \%$ of firms and $6 \%$ of employment. One of the most pronounced features of the BDS High Tech data is the significant increase in entry and young firm activity in the 1990s, which is then sharply reversed after $2000 .{ }^{4}$

The rest of the paper proceeds as follows. Section 2 describes different methods for identifying High Tech industries. We evaluate their reproducibility, ease of maintenance and overall strengths and weaknesses. Section 3 compares the list of High Tech industries that emerge across methodologies. We compare selected measures of business dynamism economy wide and for the manufacturing sector. Section 4 presents results from a set of BDS High Tech tables. Section 5 concludes.

\section{IDENTIFYING HIGH TECH INDUSTRIES}

An interagency workshop held by U.S. statistical agencies in 2004 identified a set of important factors that contribute to the concept of High Tech. ${ }^{5}$ These include disproportionately high employment of STEM workers, disproportionately high employment of R\&D workers and capital, the production of High Tech products, and the use of High Tech production methods, including the use of High Tech capital goods and

\footnotetext{
${ }^{3}$ We follow Hecker (2005) and define three levels of intensity. The highest level employs at least 5 times as many STEM workers as the economy average.

4 This is first documented in Decker et al (2015).

${ }^{5}$ See Hecker (1999) for an early overview of the topics discussed.
} 
services. ${ }^{6}$ Efforts to take this definition to the data attempt to classify economic activity based on either the use of High Tech inputs or the production of High Tech outputs. Each approach has advantages and disadvantages with respect to their use in measuring the dynamics of High Tech industries. These differences are primarily related to the availability of data and reliance on arbitrary criteria and thresholds. ${ }^{7}$ Table 1 summarizes the different methods of classification and the literature that develops them. In the following sections we detail each method as well as their pros and cons when used in the development of BDS High Tech data products.

One conceptual concern to keep in mind before proceeding is that the choice of classification methodology, whether based on inputs or outputs, will affect the type of activity measured. For the purposes of the BDS data products, we will evaluate both input and output methods as well as the amount of arbitrariness involved in each. This is relevant in as much as the statistics we generate might differ across methodologies.

\subsection{INPUTS BASED METHODOLOGIES}

\subsubsection{STEM EMPLOYMENT}

Hecker (2005) identifies a list of High Tech four-digit 2002 NAICS industries by measuring employment in "technology oriented occupations". This approach is based on the idea that firms that innovate and are engaged in R\&D employ a relatively large number of scientists, engineers, and technicians. ${ }^{8}$ In this regard, STEM workers are an input into the innovation process and can therefore be used as a proxy for identifying innovative activity in the economy. Hecker (2005) uses the 2002 Bureau of Labor Statistics (BLS) National Employment Matrix derived from the Occupational Employment Statistics (OES) survey, which provides occupational employment by four-digit NAICS industries, to calculate the proportion of technology oriented workers by industry. In order for workers in an occupation to be considered technology oriented they must be engaged in $R \& D$, the development of scientific knowledge, and/or the use of that knowledge to develop products and production processes. This includes occupations that apply technology in the design of

\footnotetext{
${ }^{6}$ See Hecker 2005 for a review.

7 See Kask and Sieber (2002) for insights.

8 The Office of Technology Assessment, "Technology, Innovation, and Regional Economic Development" report from Sept. 9, 1982 and the NSF special report "Science and Technology Resources in U.S. Industry" NSF 88-321, from December, 1988 both make this point.
} 
equipment, processes, and structures, applications related to computers and computation, sales, purchasing, and marketing, as well as quality management and management (Hecker 2005). Table 2 provides some examples of technology oriented occupations in computer and math sciences, engineering, and physical and life sciences.

Operationalizing this approach requires determining cutoffs for what ought to be considered a large number of STEM workers. Hecker (2005) defines High Tech industries as those whose proportion of STEM workers are at least twice the average proportion of STEM employment across all industries. ${ }^{9} \mathrm{~A}$ total of 46 industries meet this definition, with STEM employment at least twice the average of 4.9 percent in 2002 (see Appendix A for a listing). These industries accounted for 11 percent (14.4 million) of nonfarm wage and salary jobs in 2002. In 44 of the 46 industries median 2004 earnings were greater than overall median earnings. Similarly, when focusing on occupations, the median earnings in all of the technology oriented occupations was greater than the median for all workers except forest and conservation technicians. The earnings data suggests that the occupations identified as technology oriented indeed represent high skilled employment.

One of the challenges in using input based methods to identify High Tech industries is that they run the risk of biasing the set of industries selected as a function of the type of inputs examined. One of the strengths of the Hecker (2005) methodology is that it relies on labor inputs that are (at least for now) a standard input to the innovation production function and therefore produce results that are less likely to be biased or constrained to certain types of industries. ${ }^{10}$ The Service and Information sectors are well represented in the Hecker (2005) High Tech industries - 22 of the 46 industries identified as High Tech fall in these sectors, which include computer design services, architectural and engineering services, and data processing and hosting services amongst others. By focusing on the concentration of STEM employment, the resulting set of High Tech industries is not limited to those industries with relatively high officially-measured $R \& D$ expenditures or to those

\footnotetext{
$9 \mathrm{He}$ provides further refinement based on the intensity of High Tech. We make use of this refinement to identify industries with the highest proportions of STEM workers; those with at least five times the average.

${ }^{10}$ A mounting concern with innovation metrics is that increasingly they fail to identify certain types of innovations; for example, innovations that have a zero price or do not rely on patents or measured R\&D. What used to be the relatively simple task of tracking domestic R\&D spending by a small number of U.S. manufacturers has evolved into the need to monitor more broadly innovation, science, and technology.
} 
that produce High Tech outputs. In contrast, it might miss industries that do not rely on technology oriented workers to produce High Tech outputs or industries that utilize other types of High Tech inputs but not technology oriented workers.

One final concern about the STEM methodology is that its reliance on the relative concentration of STEM labor within narrow industries makes it sensitive to industry definitions and the boundaries of establishment activity. ${ }^{11}$ This is less of a concern in the OES data since establishments, to which 6-digit NAICS codes are assigned, that perform two or more distinct economic activities are treated as two or more separate establishments if separate payroll records are available. ${ }^{12}$

Hecker (2005) groups the 46 identified industries into three High Tech intensity levels. Level I includes 14 industries with a proportion of STEM workers at least 5 times the average. Level II includes 12 industries where the STEM proportion was 3.0 to 4.9 times the average. Level 3 includes 20 industries where the STEM proportion was 2.0 to 2.9 times the average. Between the three levels, all of computer and electronic products industries (NAICS 334) are covered and most of the telecommunications industries within the information sector, four machinery-manufacturing industries, and all but one industry in chemical manufacturing. Moreover, Hecker finds all Level I industries to be R\&D intensive and most have some "advanced technology products" as defined by the Census Bureau (NSF 2002; Census Bureau 2015).

\section{REPLICABILITY AND STABILITY}

Having the ability to replicate and update the list of High Tech industries is a critical requirement of creating and maintaining a set of statistical products that track High Tech industries. ${ }^{13}$ One advantage of the Hecker (2005) methodology is that it can be replicated

\footnotetext{
${ }^{11}$ Establishments can engage in multiple types of activities; however, the Census Bureau identifies only the dominant activity a potential source of noise. Similarly the Census Bureau identifies headquarter establishments and those offering support services independently from the industry they serve. These types of issues are discussed in greater detail in Census Bureau memorandums related to the classification of auxiliary establishments (http://www.census.gov/eos/www/naics/history/docs/cm_3.pdf accessed 10/18/2016).

12 For additional information on the sample frame and survey methods see http://www.bls.gov/oes/current/methods_statement.pdf accessed 10/18/2016).

13 The BLS recently released new statistics for High Tech industries based on the Hecker (2005) methodology. These statistics, however, do not delineate between the different levels or intensities of High Tech, which as we discuss are crucial for producing a stable classification.
} 
using more recent industry-occupation employment data from the BLS. The OES industryoccupation employment matrix is available annually between 1997 and 2014. We use the 2012 and 2014 OES data to recalculate STEM concentration ratios for 4-digit NAICS industries. ${ }^{14}$ This exercise allows us to not only produce measures that more closely resemble current High Tech industries, but also to assess how stable the Hecker (2005) classification methodology is over time. A common concern across classification methodologies is that industries that have been High Tech in the past are no longer considered High Tech and vice versa. Similarly, if there are significant movements across High Tech intensity levels this might inform our choice of the level of aggregation used in the final tabulations. Table 3 , Table 4 , and Table 5 summarize the results from that analysis. Table 3 lists the number of 6-digit 2007 NAICS industries identified as High Tech using different vintages of the OES data. ${ }^{15}$ The table disaggregates results by High Tech level.

Table 3 shows that the total number of industries identified as High Tech is remarkably stable over time. In 2005, we find there are 173 High Tech industries spanning levels I through III, which dipped to 167 in 2012 then rebounded back to 171 in $2014 .{ }^{16}$ Table 3 is useful in determining the changes in the number of industries classified as High Tech within each data vintage and level; however, it is not informative regarding changes in the actual industries covered across years and High Tech intensity levels. Table 4 and Table 5 provide this information. Table 4 shows the number of High Tech industries in the intersection of all three data vintages, as well as the number of High Tech industries specific to each data vintage. We find there are 147 industries common to all three years,

(http://www.bls.gov/opub/btn/volume-5/the-high-tech-industry-what-is-it-and-why-it-matters-to-oureconomic-future.htm accessed 6/20/2016)

${ }^{14}$ It is important to note that the public industry-occupation tables include disclosure suppressions. These suppressions are unlikely to affect our results since the cells being suppressed are often relatively small and are therefore less likely to impact the ratio of STEM employment within an industry. Moreover, in a comparison of our results to similar efforts performed by BLS that aggregate from undisclosed versions of the data, we find the same sets of industries being identified as High Tech.

15 The 2012 and 2014 OES industry-occupation employment data use 2012 NAICS industries and Hecker (2005) uses 2002 NAICS industries. We convert these to 2007 NAICS industries using public Census NAICS concordances.

${ }^{16}$ It is unclear whether changes in the number of industries reflects growth or contraction in the number of STEM workers or rather the changing fragmentation of production activities across establishments and firms. This question is beyond the scope of this paper and we do not address it here. 
which again indicates a high level of stability. We also find 24 industries were High Tech in 2005 but are no longer High Tech in 2012 and 2014. Similarly, 8 industries are High Tech only according to either the 2012 or 2014 STEM concentration ratios. ${ }^{17}$ Table 5 provides the same information by intensity level. Several things are worth pointing out. First, out of the 147 industries consistently identified across all three vintages only 107 are classified in the same level of technological intensity in all three years. A significant proportion of the industries classified as High Tech in all three years, 27\%, switch technology level over time. There is a considerable amount of fluidity not only in the types of industries that are classified as High Tech but also in the intensity level that they fall in. Second, the more consistently defined level is the highest technological group (level I) as evidenced by the number of industries in common across years versus the industries that are not, 48/11 for Level I vs 27/51 for Level III. Across the three vintages there are 60 unique 6-digit Level I industries, meaning that $80 \%$ (48) are consistently Level I over the time period analyzed. ${ }^{18}$ Third, a large part of the fluidity across definitions is caused by newly classified Level III industries. All 8 of the industries that only appear in 2012 or 2014 are classified as Level III and none of the 24 industries that only appear in Hecker (2005) are Level I. Because of the STEM methodology's reliance on the mean concentration of technology oriented workers, the Level III group is the most sensitive to small shifts in the distribution of STEM workers across industries. These results indicate that the highest intensity industries (level I) do not appear susceptible to changes in the composition of technology oriented occupations. This is not surprising. STEM employment is highly concentrated in the Level I, Level II, and Level III industries. In 2014, Level I industries accounted for 44\% of total STEM employment and all three levels accounted for 63\% of STEM employment.

To summarize, there are several advantages to using the Hecker (2005) methodology within the BDS High Tech data products. First, the Hecker (2005) method relies on readily available data and can be replicated with OES industry-occupation employment data. Second, the methodology produces a relatively stable set of industries over time, especially for the set of industries with relatively high levels of STEM workers, Level I. Third, the Hecker (2005) methodology identifies technologies across a wide set of sectors including

\footnotetext{
${ }^{17}$ See Appendix F for list of industries that are classified as High Tech in either 2012 or 2014 but not found in the original Hecker (2005) classification.

18 Note that Table 5 excludes industries that are classified as level I in some combination of two years (for example industries that appear in 2012 and 2014 but not 2005).
} 
manufacturing, services, and information. In this regard, it is important to note that it has already been used to measure the business dynamics of High Tech industries. Hathaway (2013) and Haltiwanger, Hathaway, Miranda (2014) use the STEM methodology to analyze business dynamics in Level I High Tech industries. Those analyses speak to the appeal of the methodology and provide a successful test case of applying this methodology to the BDS data more broadly.

There are also some disadvantages to using the STEM employment concentrations to identify High Tech industries. First, the cutoffs between the different levels of High Tech industries are still arbitrary. Second, the Hecker (2005) methodology requires as input a curated set of occupations identified as "technology oriented occupations". Such a list of occupations necessarily entails subjective assessment and expert review. ${ }^{19}$

\subsubsection{R\&D EMPLOYMENT AND INTENSITY}

In an earlier effort, Hecker (1999) identifies a list of High Tech three-digit SIC industries using employment in both R\&D and technology oriented occupations in the OES surveys from 1993 to 1995. In these years the OES asked employers to report the number of workers engaged in R\&D activity. Hecker (1999) identified 31 three-digit SIC industries in which the number of R\&D workers and technology oriented occupations accounted for a proportion of employment that was at least twice the average for all industries surveyed. He finds these industries had at least 6 R\&D and 76 technology oriented workers per 1,000 workers. The list of 1997 NAICS codes identified as High Tech, concorded from the original list of SIC codes by the Office of Technology Policy and the Census Bureau (NSF 2003), are shown in Appendix B. The Hecker (1999) methodology uses more information than Hecker (2005) and has been used by the NSF in their Science and Engineering Indicators publication to define High Technology industries. ${ }^{20}$ However, it is important to note that the list of identified industries skews heavily towards manufacturing where R\&D as an

\footnotetext{
19 The Standard Occupation Classification Policy Committee (SOCPC) formed a working group that included a number of government agencies to develop a standard definition for STEM occupations. The working group's recommendations were and submitted to the Office of Management and Budget (OMB) in 2012. For additional information see Attachment A: Options for defining STEM occupations under the 2010 Standard Occupational Classification (SOC) system (http://www.bls.gov/soc/Attachment_A_STEM.pdf accessed 10/18/2016).

20 See chapter 8 of the NSF Science and Engineering Indicators 2006. Technical Note: Defining High-Technology Industries. http://www.nsf.gov/statistics/seind06/c8/c8.cfm?opt=9
} 
expense category is more easily measured. Furthermore, this methodology relies on $R \& D$ employment data no longer collected in the OES survey and more current NSF R\&D employment data from the Business R\&D and Innovation Survey (BRDIS) appears to have only limited comparability to the original OES measures (Hecker 2005). The NSF no longer uses this methodology to identify High Tech firms in favor of the OECD methodology that focuses instead on measures of R\&D intensity.

The OECD has produced a classification scheme to identify High Tech industries using R\&D intensity. That classification scheme has been used by statistical agencies around the world to develop economic statistics describing High Tech industries. Indeed one of the primary goals for developing such a classification scheme was to promote comparability of relevant statistics across countries. ${ }^{21}$ The OECD's R\&D intensity classification scheme is based upon Hatzichronoglou's (1997) measures of direct and indirect R\&D intensity for 22 ISIC Rev. 2 manufacturing industries. Behind this approach is the idea that R\&D is a key input to innovation and that High Tech firms devote a "high" proportion of expenditures to R\&D activities. This input based measure forms the basis for the R\&D intensive and High Tech statistics in the OECD's Science, Technology, and Industry (STI) Scoreboards. ${ }^{22}$ Hatzichronoglou (1997) uses data from R\&D surveys conducted in ten OECD countries between 1980 and 1990. The structure of these surveys in more recent years is guided by the Frascati Manual of proposed standards and practices (OECD 2002). Hatzichronoglou (1997) measures direct R\&D intensity of an industry as R\&D expenditures divided by total industry value added or output. Indirect $R \& D$ intensity is measured using input-output tables to account for the technology embodied in intermediate and investment goods. Finally, Hatzichronoglou (1997) uses these measures of direct and indirect R\&D intensity to group each of the 22 manufacturing industries into high-technology, medium-hightechnology, medium-low-technology, and low technology classes. The original measures were calculated over a long period, using data between 1980 and 1990, which helped ensure that the indicators would remain stable over time. ${ }^{23}$ The high-technology manufacturing group includes: aerospace (3845), computers and office machinery (3825), electronics and communications (3832), and pharmaceuticals (3522).

\footnotetext{
21 the National Science Foundation uses the OECD's R\&D intensive industries to characterize trends in High Tech industries in their Science and Engineering Indicators (NSF 2010 p. 6-8).

22 The STI Scoreboard is a compendium of comparable cross country statistics.

${ }^{23}$ See Hatzichronoglu (1997), pg 5.
} 
The OECD has published several updates to the Hatzichronoglou (1997) classification scheme. The list of High Tech industries was updated in 2003 to use ISIC Rev. 3 industries and leverage additional survey data for 1991-1999 (OECD 2003). These industries are shown in Appendix C. The most recent update, incorporated in the 2015 STI Scoreboards reclassifies High Tech manufacturing industries using ISIC Rev. 4. The High Tech manufacturing industries now include Pharmaceuticals (Division 21), Computer, electronic and optical products (Division 26) and Air and spacecraft and related machinery (Group 303).

Recognizing the inherent limitations of using R\&D data, the OECD has also classified High Technology services. Owing to the lack of detailed services data across countries, the 1999 STI Scoreboard identified High Tech service industries as all those that fell in the broad group "Finance, insurance, real estate and business services" (ISIC Rev. 2, division 8). This was updated in the 2001 STI using limited R\&D intensity data for services sectors to include: division 64 post and telecommunications, divisions 65-67 finance and insurance, and divisions 71-74 business activities (not including real estate), education, and health (OECD 2001 p. 124). ${ }^{24}$ The most recent revision of the OECD's R\&D intensive industry classification was published in 2015 and includes agriculture, mining, utilities, construction, and a broad range of service industries (OECD 2015b). Given data limitations, the selected set of service industries is relatively broad.

\section{REPLICABILITY}

The OECD recognizes that a different set of industries might result by applying the same Hatzichronoglou (1997) methodology to country specific R\&D surveys. ${ }^{25}$ A U.S. specific list of High Tech industries could be produced using R\&D measures found in the NSF's BRDIS, but there are currently no efforts underway to generate such a list. ${ }^{26}$ However, replicating the OECD methodology using the U.S. R\&D survey data requires resolving a number of methodological questions. First, R\&D surveys are skewed away from small and young R\&D

\footnotetext{
24 The NSF Science and Engineering Indicators 2016 describes knowledge intensive service industries as "those that incorporate science, engineering, and technology into their services or the delivery of their services, consisting of business, information, education, financial, and health services." Commercial knowledge intensive services are business, information, and financial services. 25 See remarks to summary page, "ISIC Rev. 3 Technology Intensity Definition", http://www.oecd.org/sti/ind/48350231.pdf.

${ }^{26}$ See NSF Science and Engineering Indicators 2016, pg 44.
} 
performers, a disproportionally innovative and dynamic set of firms (Acemoglu et al 2013, Graham, Grim, Islam, Marco, and Miranda 2014). Moreover, there is no clear methodology for grouping the industries by level of R\&D intensity. For instance, the R\&D intensive manufacturing industries appear to have been grouped into high, medium-high, medium, and low-tech manufacturing industries somewhat arbitrarily.

The NSF's motivation for using the OECD's R\&D intensity classification scheme is one of its primary advantages; namely, its international comparability. This is also one of its biggest drawbacks. International comparability and data limitations require identifying a set of ISIC industries that are relatively broad. Industries listed as R\&D intensive in one country may not be R\&D intensive in another country (OECD 2015a p. 28). As discussed in section 3.1, this is particularly problematic in the U.S. where mapping the High Tech ISIC industries into 6-digit NAICS industries yields many service industries that are not High Tech. Furthermore, as noted in Hatzichronoglou (1997), R\&D intensity measures are biased against industries that experience periods of high demand growth in which R\&D expenditures increase less rapidly. Similarly, it can overstate the contribution of R\&D in small, growing industries. Finally, the OECD, referencing a wide body of literature indicating that innovation is much broader than R\&D intensity, cautioned against interpreting R\&D intensive industries as technology-intensive (OECD 2015b p. 1).

\subsection{OUTPUT BASED METHODOLOGIES}

\subsubsection{CENSUS BUREAU ADVANCED TECHNOLOGY PRODUCTS}

The Census Bureau has developed a list of "advanced technology products" (ATP) using the Harmonized System (HS) product codes available in administrative trade data. The goal of this exercise is to produce trade statistics for advanced technology goods. The classification scheme covers both imports and exports and goes back at least to 1989. This set of products includes 10 broad technology areas: biotechnology, life science technologies, optoelectronics, information and communications, electronics, flexible manufacturing, advanced materials, aerospace, weapons, and nuclear technology. In order to be included in one of these categories a product must contain a "significant amount of one of the leading-edge technologies, and the technology must account for a significant portion of the product's value" (NSF 2002). The Census Bureau maintains concordance files mapping 10-digit HS 
codes to each technology area. ${ }^{27}$ The 2012 crosswalk includes 389 HS codes for exports and 514 HS codes for imports. The BLS assigned the high-level product groups to 4-digit 2002 NAICS codes (Hecker 2005). These industries are shown in Appendix D.

\subsubsection{R\&D INTENSIVE PRODUCTS}

Hatzichronoglou (1997), in addition to the R\&D intensity measures described in section 2.1.2., also developed a High Tech classification methodology based on products. The methodology used calculations of $R \& D$ intensity by groups of products (R\&D expenditure/total sales). These SITC Rev. 3 product codes are shown in Appendix E. Relatively little information is available to describe the methods used to define High Tech products. Most OECD publications now rely on industry approaches based on R\&D intensity described in the previous section rather than the classification of products.

\section{LIMITATIONS OF OUTPUT BASED METHODS}

Regardless of the source or structure of the product codes identified as High Tech, for the purposes of the BDS statistics, these products would need to be translated to NAICS industries. The BLS translation of the Census ATPs relies on manual curation and does not provide an appropriate level of industry detail for the purposes of the BDS High Tech data products. One method of translating the Census ATPs to industry codes would be to leverage the Longitudinal Foreign Trade Transactions Data (LFFTD) to identify the industries in which firms are importing and exporting ATPs. However, mapping product codes associated with trade transactions to specific industry codes is a non-trivial exercise, especially given that large trading firms typically operate across multiple industries. A clear limitation of this approach is that, due to the nature of the trade transaction data, the resulting list would be heavily skewed towards manufacturing industries.

\section{COMPARING HIGH TECH METHODOLOGIES}

\subsection{INDUSTRY COVERAGE}

Despite the very different methodologies used to create the STEM concentration, R\&D intensity, and product classification schemes, there is significant overlap in the resulting

${ }^{27}$ Census Bureau Foreign Trade Statistics, https://www.census.gov/foreign-trade/reference/codes/atp/index.html (accessed 11/24/2015) 
industries identified, particularly when focusing on manufacturing industries. For example, all four ISIC Rev. 4 High Tech industries used in the 2015 OECD STI report, pharmaceuticals, computer, electronic and optical products, and air and spacecraft and related machinery, are represented in the Hecker (2005) Level I industries as well as the recalculated STEM 2012 and STEM 2014 Level I industries. Moreover, industries identified as High Tech in earlier OECD STI reports such as medical, precision and optical instruments, and radio, TV, and communications equipment are also captured in the Level I STEM concentration industries. Similarly, 9 of the 16 4-digit 2002 NAICS industries covered under the Census Bureau's "advanced technology products" appear in the Hecker (2005) Level I industries. Three of the remaining seven industries are found in Level II and none in Level III.

In order to perform a more thorough comparison of the makeup of the High Tech industries identified by different methodologies we translate each set from its native industry scheme to a common 6-digit 2007 NAICS industries. As with any application requiring the translation across industrial classification systems, there is some measure of ambiguity in the final concordance. Specifically, the Hecker (1999) High Tech industries include a combination of 4, 5, and 6-digit 1997 NAICS industries. We translate the 4 and 5digit industries to the 6-digit 1997 NAICS industry classification system, then concord at the 6-digit level to the 2007 NAICS industry classification system using the Census Bureau NAICS concordances. ${ }^{28}$ The OECD (2003) High Tech industries include a combination of 2 , 3, and 4-digit ISIC Rev. 3 industries, which we first translate to the 4-digit ISIC Rev. 4. industry classification system then to the 6-digit 2007 NAICS industry system using the United Nations concordances. ${ }^{29}$ The recently revised OECD (2015) R\&D intensity industry classification includes 2 and 3-digit ISIC Rev. 4 industries, which we translate to 6-digit 2007 NAICS industries. At each step, it is possible that one industry in the original classification maps to multiple industries in the new classification and/or vice versa. For example, in the case of the OECD's R\&D intensive classifications, some of the original ISIC industries are relatively aggregate, such as 31 Medical, precision, and optical instruments. This high level of aggregation means one ISIC industry will ultimately map to many 6-digit 2007 NAICS industries. In addition, due to the many-to-many nature of this translation, it

$28 \mathrm{http}: / /$ www.census.gov/eos/www/naics/concordances/concordances.html (accessed 01/21/2016)

29 http://unstats.un.org/unsd/cr/registry/regot.asp?Lg=1 (accessed 01/21/2016) 
is not always possible to assign a unique ISIC based High Tech intensity level to a given NAICS (i.e. the same NAICS can be classified as high and medium-high according to its mapping to ISIC codes). In such cases, we select the lowest classification level. ${ }^{30}$

Table 6 shows the number of 6 -digit industries identified by each methodology as High Tech across major sectors. All methodologies identify a large number of manufacturing industries as High Tech. The Census ATP classification focuses heavily on manufacturing. The STEM concentration methods and OECD definitions also identify a significant number of information and services industries as High Tech. The 2003 vintage of the OECD method identifies 50 industries within the Finance, Insurance, and Real Estate, far more than any other method. Additionally, the 2003 OECD classification identifies twice as many industries as High Tech compared to the STEM methods. Note that the services sector here includes both professional services (54) and other non-public administration services (81). Examining the detailed industries included by the 2003 OECD classification we begin to see the ambiguity and noise inherent in translating two digit ISIC Rev. 3 codes to 6-digit 2007 NAICS codes. For example, within the services sector, the OECD method identifies six industries under 812 Personal and Laundry Services as well as Grantmaking Foundations (813211) as High Tech. ${ }^{31}$ Also, under the Arts \& Accommodation sector, the OECD method includes Agents and Managers for Artists, Athletes, Entertainers, and Other Public Figures (711410) as High Tech. The 2015 vintage of the OECD classification has backed away from the broad identification of service as High Tech and now identifies many fewer service industries. It is now very much a manufacturing sector classification. Next, we use the alternative classifications to build selected business dynamics statistics and explore their broad patterns. Before doing so we turn to a discussion of issues related to the development and interpretation of BDS High Tech data products.

\subsection{BUILDING THE BUSINESS DYNAMICS STATISTICS OF HIGH TECH FIRMS}

\footnotetext{
30 As an example, in the original ISIC Rev. 3 codes, ISIC 33 is high tech, ISIC 29 is medium-high tech, and ISIC 36 is low tech. Once mapped to 4-digit ISIC Rev. 3.1 and concorded to the 6-digit 2002 NAICS industries, all three 2-digit ISIC Rev. 3 industries map to 2002 NAICS 238290 Other Building Equipment Manufacturers, meaning that industry is simultaneously classified as high, medium-high, and low tech. In this case, we select the lowest technology group, meaning 238290 would be considered a low technology industry.

31 Coming through ISIC Rev 32 -digit 74 to 4-digits 7412, 7413, 7414, 7421, 7422, 7430, 7491, 7492, $7493,7494,7495,7499$ which concords to ISIC Rev $3.19309,7494,5260,6420$, which concords to 2002 NAICS 812.
} 


\subsubsection{METHODOLOGICAL CONSIDERATIONS}

One of the most compelling dimensions of the existing BDS data is the length of its time series. The BDS data are available back to 1976. This allows researchers to examine not only how the U.S. economy is changing over time but also how it responds to specific shocks. However, producing BDS High Tech data products over this long time period introduces a number of issues related to interpretation and longitudinal consistency of the series. All of the methods described in the previous sections identify a set of High Tech industries at a point in time. This is true for the STEM methodology, which relies on point in time estimates of occupational concentrations across industries, and the OECD R\&D intensity measures, which relies on point in time estimates of R\&D expenditures and industry output. Moreover, though the classifications produced by the STEM methodology are relatively stable, the definition of High Tech does change over time. Industries that were High Tech a few years ago may no longer be High Tech today while new High Tech industries are appearing that did not exist before. Due to these changes over time, we might be concerned that the BDS High Tech measures will be sensitive to the choice of vintage. Put differently, which vintage is used has implications for the interpretation of the dynamism measures we create since they will be specific to a particular set of industries and therefore a specific set of technologies or point in time. ${ }^{32}$ There is a trade off, therefore, between how often to update the classification scheme and how broad to make the set of industries we track. Broader measures will be more stable over time but noisier and less descriptive of High Tech sectors. Alternatively one might focus on a set of industries that is relative stable (e.g. Level I) and to pool the industries classified as High Tech Level I across several years. Ultimately, how much we need to worry about this depends on how sensitive the business dynamics statistics are to the vintage used. We turn to this now.

Figure 1 shows firm entry rates in High Tech manufacturing according to several different aggregations of the STEM classifications using 2005, 2012, and 2014 occupation data. We focus first on the Manufacturing sector since this is the one sector where all the alternative measures are most directly comparable. Firm entry rates are produced for Level I industries (the most STEM intense industries) as well as all three High Tech levels combined. Turning to Level I industries, several patterns are worth highlighting. First, all

${ }^{32}$ Note that this is less of a concern for the STEM Level I industries, which are more stable over time. 
series regardless of vintage show considerable decline in entry rates over time, which is consistent with well-established economy wide patterns. Second, there is a slight difference across the different STEM groupings in the 1980s but by 1990 the rates converge. This is to be expected given that as we move back in time the more current classifications become less representative of High Tech sectors in the past. The more relevant takeaway, however, is that the Level I STEM measures are not very sensitive to the choice of vintage. The difference between the different STEM measures is less than 1 entry point at its widest point. This is not surprising given the significant overlap in industry coverage across STEM methodologies within the Level I group. Recall 80\% of Level I industries appear in 2005, 2012, and 2014 STEM High Tech industries. ${ }^{33}$ The 2012 and 2014 Level I measures are actually identical because, for the manufacturing sector, they happen to include the same $6^{-}$ digit NAICS industries.

The patterns for the broader technology classification, which combine all High Tech levels, are similar. We still find there are small differences across vintages with a gap of less than 1 entry point at its widest point. Importantly, comparison of the narrower versus the broader High Tech definitions shows Level I High Tech manufacturing industries experience a considerably steeper decline in firm entry rates. The decline in Level I High Tech industries is about $20 \%$ steeper than the combined groupings. The decline for Level I industries is roughly 9 entry points versus roughly 7.5 entry points for the combined set of Level I, Level II, and Level III industries.

Figure 2 shows firm entry rate statistics for all High Tech industries including those outside of manufacturing. Several things are worth noting. First, the patterns are quite different from those in manufacturing. High Tech industries outside of manufacturing experienced a very dynamic period of high entry rates in the mid 1990s that was reversed in the late 1990s and early 2000s. ${ }^{34}$ Second, Level I High Tech industries appear to be particularly sensitive to the underlying economic forces driving these changes since they experience both steeper growth and decline. This suggests that using a broader classification scheme might prevent us from recognizing shocks affecting the more intensely High Tech industries. Overall, across all of the STEM classifications, the time series

33 Other measures of dynamism across other sectors show similar patterns of agreement among the STEM and R\&D methodologies.

34 This is in agreement with findings in Decker et al. (2016) 
patterns show a high correlation rate. On average across the series the correlation is 0.99 for both manufacturing and economy wide. ${ }^{35}$

Figure 3 compares High Tech manufacturing firm entry under both the OECD 2003 and OECD 2015 methodologies as well as the Census Bureau Advanced Technology Products classification. As with STEM manufacturing, the OECD manufacturing High Tech classifications show a steep trend decline in entry rates over this period. The vintage used for defining the OECD High Tech industries, at least for manufacturing, does not matter much despite more then a decade between the data underlying the two classifications. Regardless, it is not surprising given the level of overlap between the OECD industries, ATP industries, and STEM industries that these series track each other in levels as well as trend.

Figure 4 shows firm entry rate statistics for all High Tech industries, including those outside of manufacturing, based on the OECD and Census classifications. As before, we see the OECD classification and the Census classification misses some important dynamics captured by the STEM classification. The average correlation between the OECD and Census ATP series is 0.99 for manufacturing and 0.80 for all High Tech industries. ${ }^{36}$ Figure 1 and Figure 2 suggest that, in the case of the STEM concentration methodologies, the choice of vintage does not have as great an impact on the measures of dynamism as one might have expected. The more relevant dimension is the breath of industries covered by the different methods. Despite the stability of these measures, the choice of vintage still matters for their interpretation. The more recent vintages are not as descriptive of the High Tech industries of the past. The Hecker 2005 and OECD 2003 classifications more accurately reflect High Tech activity in the 1980s and 1990s relative to the more recent STEM 2014 and OECD 2015 classifications. The older vintages are also not as representative of newer technologies and industries. An important consideration then is how frequently the classification scheme could or should be updated. The BLS industryoccupation employment matrix is published annually and updates to the OECD R\&D intensity measures occur every few years. Depending on the methodology selected, a new

35 This statistic is the mean pairwise correlation between each of the series. The minimum correlation for manufacturing and economy wide is more than 0.98 and 0.97 respectively and the maximum correlation for both manufacturing and economy wide is 1 .

36 The minimum correlation for manufacturing and economy wide is more than 0.98 and 0.68 respectively. 
classification scheme could be generated either annually or every few years. With each set of new industries, a new time series would be produced. However, updating the High Tech classification frequently creates potential disclosure problems. ${ }^{37}$ Solutions to this problem include creating noise infused statistics or moving to lower frequency updates. ${ }^{38}$

\section{INTRODUCING BDS HIGH TECH}

\subsection{BDS HIGH TECH DEFINED}

After weighing issues related to the coverage, stability, interpretation, and replicability of different classification methodologies, we chose the union of Level I industries according to the concentration of STEM employment in 2005, 2012, and 2014 as our preferred methodology for the BDS High Tech data products. One motivating factor for this decision is that the STEM concentration method captures High Tech activities outside of the manufacturing sector. As shown in section 2.1.1, the Level I industries change very little over time. Moreover, pooling High Tech industries across years will make the classification scheme even more stable. Pooling the STEM years also yields a relatively clear interpretation of the final data series. The resulting statistics capture the current and historical performance of industries that were High Tech in the past decade. They do not capture the business dynamics of industries that were High Tech in the late 1970s and 1980s but are no longer High Tech. In order to avoid issues of complimentary disclosure and discontinuities in definitions, we intend to fix the classification scheme for several years as opposed to updating annually with new industry-occupation data.

The STEM union includes 15 4-digit 2007 NAICS industries shown in Appendix H. The STEM union covers industries in mining, manufacturing, information, and professional services. Comparing this list of industries to those found in Hecker (2005), we see two additional industries, Oil and Gas Extraction (2111) and Other Information Services (5191). Though this set of industries is not drastically different from those in Hecker (2005), updating the list based on more recent occupation data allows the list to be more broadly representative of High Tech industries in the 2005-2014 time period.

\footnotetext{
37 The differential industries would be subject to disclosure analysis, greatly increasing the burden on analysts and disclosure officials and possibly the number of suppressed cells.

38 Noise infusion is a disclosure protection method that obviates the need for secondary cell suppression by ensuring that no single cell is disclosive. See Evans et al (1998) for a description of this approach.
} 
In addition to the identifying the industries of interest, we must also deal with issues relating to changing industrial classification systems across years in the underlying microdata. Prior to 2002, establishments in the LBD were classified by SIC. Between 2002 and 2014 establishments are assigned NAICS codes using some combination of the 1997, 2002 , and 2007 vintages depending on the year in question. For the construction of the BDS High Tech data products, we leverage the work by Fort and Klimek (2014) to apply consistent industrial classification codes to all establishments in the underlying microdata. Their methodology uses information from Economic Censuses, administrative data and a variety of industry concordances to do this assignment. Ultimately, they are able to assign a single complete 6-digit 2007 NAICS code to all establishments in the data for years 1976 through 2014. While Fort and Klimek (2014) allow industry classifications for each establishment to vary over time, for our purposes we select a single, time-invariant industry code for each establishment. ${ }^{39}$ To do this, we select either the industry code associated with the most recent Economic Census year or, in cases where the establishment was never covered in an Economic Census, the modal industry code. ${ }^{40}$ Having these consistent industry codes allows us to use our list of High Tech industries to produce business dynamics statistics for all the years covered by the BDS.

\subsection{BDS High Tech Statistics}

The BDS High Tech data products measure job creation and destruction from establishment entry and exit as well as expansion and contraction across relevant characteristics including firm age and firm size. ${ }^{41}$ Job creation and destruction statistics are defined following Davis, Haltiwanger and Schuh (1996) as follows:

$$
J C_{s t}=\sum_{\substack{i \in s, g_{i t} \geq 0}}\left(E_{i t}-E_{i t-1}\right) \quad J D_{s t}=\sum_{\substack{i \in s, g_{i t}<0}}\left|\left(E_{i t}-E_{i t-1}\right)\right|
$$

Where establishment-level employment growth is defined as:

\footnotetext{
${ }^{39}$ Industry codes can change for a variety of reasons some legitimate (e.g. changes to production lines) some less so (e.g. errors and non response).

40 This is consistent with the methodology in the BDS.

${ }^{41}$ We exclude tables by SIC sector due to the imprecise mapping of SIC and NAICS. While the BDS High Tech classification scheme is based on NAICS industries the existing BDS tables use 1-digit SIC sectors. Until all BDS tables are transitioned to NAICS industry codes we will not be producing industry tables for BDS High Tech.
} 
$g_{i t}=\left(E_{i t}-E_{i t-1}\right) / X_{i}$

where

$X_{i t}=0.5 *\left(E_{i t}+E_{i t-1}\right)$

The net change in employment for establishments in group $s$ satisfies the following identity:

$N E T_{s t}=\sum_{i \in s}\left(E_{i t}-E_{i t-1}\right)=J C_{s t}-J D_{s t}$

Growth rates are given by:

$J C R_{s t}=J C_{s t} / X_{s t} \quad J D R_{s t}=J D_{s t} / X_{s t}$

$N E T R_{s t}=N E T_{s t} / X_{s t}=\left(J C_{s t}-J D_{s t}\right) / X_{s t}$

where

$X_{s t}=\sum_{i \in s} X_{i t}$

is the sum of average employment over a consecutive two-year period. This growth rate measure is standard in analysis of establishment and firm dynamics. It shares useful properties of log differences but also accommodates entry and exit (Davis, Haltiwanger and Schuh 1996; Tornquist, Vartia, and Vartia 1985). These measures are equivalent to the ones used in the construction of the existing BDS statistics. ${ }^{42}$

We provide a preview of selected statistics here as an example of the types of measures included in the BDS High Tech data. The share of firms in High Tech industries is relatively small but it has grown considerably. On average between 1977 and 2014 High Tech industries account for about $3.5 \%$ of firms and $6.2 \%$ of employment. Figure 5 shows how the share of firms and employment in High Tech industries has changed over time. Since the classification of High Tech is based upon industry, and industry is an establishment level characteristic, firms may be classified as both High Tech and non-High

42 See http://www.census.gov/ces/dataproducts/bds/methodology.html for details on the BDS statistics. 
Tech. With that in mind, High Tech firm share in Figure 5 measures the total number of firms with at least one establishment in a High Tech industry divided by the total number of firms in the economy. Since employment occurs at the establishment level, High Tech employment share simply captures the percent of employment in High Tech industries. The figure suggests that while the overall share of firms in High Tech industries has more than doubled since 1980, High Tech employment share has been relatively flat and trending slightly up since 2005 .

Figure 6 shows the job creation rates in High Tech and non-High Tech industries. We see three distinct periods in the High Tech job creation rate series. First, a declining trend similar to that found in non-High Tech industries from 1977 through the early 1990s, followed by a marked increase in the High Tech job creation rate during the 1990s, and finally a return to decline in the post 2001 period. Much of these trends can be explained by changes in firm entry. Figure 7 shows the firm entry rate for the High Tech and non-High Tech sectors. In the non-High Tech sector, the firm entry rate exhibits the familiar secular decline found in many recent studies (Decker et al. 2014). In High Tech, on the other hand, the firm entry rate undergoes a sharp increase from 1992 to 1998, then returns to the declining trend, actually falling faster than non-High Tech by the end of the series. ${ }^{43}$ Rising job creation and entry in High Tech during the 1990s corresponds to a period of rapid technological progress in information technology producing sectors, which dramatically reduced prices. Across the economy, firms increased their investments in information technology capital. These investments accounted for upwards of three-quarters of post-1995 labor productivity growth (Sichel and Oliner 2002, Jorgenson, Ho, and Stiroh 2002). The responsiveness of business to productivity shocks also increased during this time leading to improvements in allocative efficiency and productivity growth (Decker et al. 2016c). The use of information technology played a transformational role in the 1990s by decreasing costs, improving business processes and work practices, and introducing new products or improving existing products (Brynjolfsson and Hitt 2000).

Even more dramatic than the High Tech boom was the subsequent bust. In Figure 8 we show High Tech job creation and job destruction rates. The fall in the High Tech job creation rate is accompanied by a sharp increase in the High Tech job destruction rate in

43 These patterns have been documented in Haltiwanger et al. (2014) and Decker et al. (2016a, 2016b). 
2002 following the collapse of the dot-com bubble. In analyses of the microdata underlying these tabulations, we find these dynamics are driven in large part by the Computer Systems Design and Related Services (5415) and Architectural, Engineering, and Related Services (5413) industries. ${ }^{44}$ These industries provide services such as custom computer programming, computer systems design, computer facilities management and other specialized design services to other firms. The sharp declines in High Tech occurred while there was a fundamental shift in productivity growth. In the post-2000 period the contribution of both information technology production and use to productivity growth began to recede from their extraordinary rates of the 1990s (Jorgenson, Ho, and Stiroh 2008, Fernald, 2014). Interestingly, the post-2000 declines in these industries, which we identify based on their relatively high levels of STEM employment, also coincides with falling demand for high skilled labor (Beaudry, Green, and Sand 2013).

To further investigate how these patterns vary across different types of firms we compare job creation by firm age. Figure 9 shows the share of job creation accounted for by startups, young firms, and middle-aged firms. In Figure 9, the increased contribution of startups and young firms to job creation in High Tech in the 1990s is dramatic, rising by 5\% and $10 \%$ points respectively. The decline is equally dramatic in the years leading up to the Great Recession. Decker et al (2016c) show young High Tech firms displayed a pattern of increased then decreased responsiveness to idiosyncratic shocks during this time contributing to the increase and then decline in productivity growth. The contribution to job creation from firms 6 to 10 years old fell through 2002. In the post 2000 period all three series appear to converge.

Though focusing on young firm activity can be informative, the BDS High Tech data allow us to examine these trends across the full range of firm age and size categories. Figure 10 and Figure 11 show the average job creation rates for High Tech industries for the 1983-1992, 1993-2001, and 2001-2014 periods. These periods correspond to the decline, rise, and fall in job creation rates (Figure 6) and share of young firms (Figure 9). In Figure 10 we see that the rise and fall of job creation was much more dramatic for young firms relative to older firms. Interestingly, job creation for the oldest group of firms (those born before 1977) has grown slowly throughout. Figure 11 shows the job creation rates for High 
Tech industries by firm size using the same time periods. Here we see that the job creation rate of the smallest High Tech firms, those between 1 and 4 employees, has been in decline over the entire year range with the boom period in the late 1990s simply slowing that trend. Medium sized firms experienced patterns similar to young firms-briefly increasing job creation rates in the late 1990s then returning to a declining trend thereafter. The largest High Tech firms, as with the older firms, saw rising job creation rates throughout. These patterns highlight the heterogeneity in the trends in High Tech across different types of firms.

Importantly, these statistics highlight the dramatic changes occurring in the High Tech sector over time and how those changes differ from trends in the non-High Tech sector. Figure 12 shows the firm age distribution by High Tech and non-High Tech and its evolution between 1987 and 2014. High Tech is increasingly dominated by older firms. As the sector matures, the share of young firms (those up to 5 years old) declined from $56 \%$ in 1987 to $37 \%$ in 2014 . The decline in startups and young firm activity follows the secular trends in the non-High Tech sector. The temporary boom during the 1990s is clearly identifiable in the High Tech figure. Figure 13 shows the employment weighted firm shares by firm size groups in the High Tech and non-High Tech sectors. High Tech employment is increasingly concentrated in smaller firms. As the sector matures the share of employment at large firms (those with 5,000 or more employees) declined from 67\% in 1977 to $44 \%$ in 2014-a 23 point decline. ${ }^{45}$ These trends are markedly different from the trends we observe in the rest of the economy. In the non-High Tech sector employment activity is slowly shifting towards the largest firms. The shift away from small firms, 6 points between 1977 and 2014 from $40 \%$ to $34 \%$, largely reflects a decline in young firm activity, many of whom tend to be small.

Digging deeper into the nature of the changing nature of the High Tech sector we find dramatic changes in the average establishment size. Figure 14 shows the average establishment size for firms in High Tech and non-High Tech by firm size. The left panel shows how the average size of establishments of large High Tech firms has experienced a $71 \%$ decline from its peak in 1983. These declines are much sharper than the declines observed in the rest of the economy where establishment size at large firms declined by

${ }^{45}$ During this time the share of High Tech firms with 5,000 or more employees fell from $0.85 \%$ to $0.33 \%$. 
only $17 \%$ in the same period. The sharp decline in establishment size at large firms is potentially due to shifts in industry composition in High Tech over this period-with production moving away from manufacturing and towards services and information service providers along with changes in production technology that allow for increased fragmentation of production.

Finally, the BDS High Tech data also allows for the exploration of geographic variation in High Tech firm and employment measures. We might expect employment in the High Tech sector to be relatively concentrated. A number of studies have demonstrated the importance of regional clusters and the geographic concentration of innovative activity (Fujita, Krugman, and Venables 2001, Delgado, Porter, and Stern 2010). Figure 15 shows the average share of High Tech employment by state between 2012 and 2014. There is significant geographic variation in the percent of employment in High Tech industries ranging from Virginia with $11.1 \%$ to Mississippi with $2.4 \%$. We find the highest proportion of High Tech employment in Virginia, Washington, Maryland, and Massachusetts, followed by California and the District of Columbia. For High Tech firm share, we find the top three states have an average of $6.4 \%$ of firms in High Tech industries whereas states at the bottom average 3\%. These geographic differences largely persist over time.

To summarize, these figures demonstrate the ways in which the BDS High Tech data can be used to examine the business dynamics in High Tech industries. High Tech industries experienced a surge of entry and young firm activity in the 1990s that was abruptly reversed in the early 2000s. Since then, job creation rates have returned to previous trend declines. The 1990s then appear to represent a break within an otherwise broader secular decline. Firm entry rates in the High Tech and non-High Tech sectors are now converging. It appears that the boom-bust phenomena in High Tech is concentrated among young relatively small firms-larger older High Tech firms weathered the early 2000s much better than did young small firms.

The BDS High Tech statistics shed light on important structural changes in the U.S. economy. The share of firms in High Tech is increasing over time. However, the share of employment in High Tech industries has remained stable over the last 30 years. The dynamics underlying these trends are dramatically different across firm age and size categories. High Tech is increasingly dominated by older and smaller firms. This is because 
employment is shifting away from large firms. The average size of establishments for the largest High Tech firms has declined significantly. This is in stark contrast with the nonHigh Tech sector where there is a significant and well-documented shift in employment away from small firms and establishment size has not declined as much. Finally, geographic variation in High Tech activity is significant and persistent.

\section{CONCLUSION}

The reallocation of labor and capital is an important driver of economic growth and rising living standards. Businesses in the High Tech sector play a particularly important role in this reallocation process by introducing new and improved products and services. This paper describes an extension of the existing BDS statistics that improves our understanding of this important and dynamic portion of the economy. Despite significant interest in measuring High Tech economic activity, there is little consensus on how best to identify High Tech businesses. We survey some of the existing methodologies, including input and output based methods, with an eye to their application in producing BDS statistics for High Tech industries. Based on coverage, stability, interpretation, and replicability, we chose the union of Level I industries according to the proportion STEM employment in 2005, 2012, and 2014 as our methodology for identifying High Tech industries. Finally, we leverage the existing data infrastructure used to produce new BDS statistics focusing specifically on the business dynamics of High Tech industries.

The BDS High Tech data products provide new measures of job creation and destruction, entry and exit in High Tech industries by a number of relevant firm characteristics including firm age and firm size. In this paper, we preview some of the resulting statistics and demonstrate their utility in better understanding trends in High Tech. We show the High Tech sector experienced dramatic structural shifts during the last 30 years with a short burst of extraordinary dynamism in the 1990s. 


\section{REFERENCES}

Acemoglu, D., Akcigit, U., Bloom, N., \& Kerr, W. R. (2013). Innovation, reallocation and growth (No. w18993). National Bureau of Economic Research.

Beaudry, P., Green, D. A., \& Sand, B. M. (2013). The great reversal in the demand for skill and cognitive tasks (No. w18901). National Bureau of Economic Research.

Brynjolfsson, E., \& Hitt, L. M. (2000). Beyond computation: Information technology, organizational transformation and business performance. The Journal of Economic Perspectives, 14(4), 23-48.

Census Bureau Foreign Trade Statistics. (2015). Retrieved January 14, 2015, from https://www.census.gov/foreign-trade/reference/codes/atp/index.html

Davis, Steven J., John C. Haltiwanger and Scott Schuh. (1996). Job Creation and Destruction. Cambridge, MIT Press.

Decker, R., Haltiwanger, J., Jarmin, R., \& Miranda, J. (2014). The role of entrepreneurship in US job creation and economic dynamism. The Journal of Economic Perspectives, 28(3), 3-24.

Decker, R. A., Haltiwanger, J., Jarmin, R. S., \& Miranda, J. (2016a). Declining Business Dynamism: Implications for Productivity?.

Decker, R. A., Haltiwanger, J., Jarmin, R. S., \& Miranda, J. (2016b). Where has all the skewness gone? The decline in high-growth (young) firms in the US. European Economic Review, 86, 4-23.

Decker, R. A., Haltiwanger, J., Jarmin, R. S., \& Miranda, J. (2016c) "Changing Business Dynamism and Productivity: Shocks vs. Responsiveness." Mimeo.

Delgado, M., Porter, M. E., \& Stern, S. (2010). Clusters and entrepreneurship. Journal of Economic Geography, 10(4), 495-518.

Evans, T., Zayatz, L., Slanta, J., (1998). Using noise for disclosure limitation of establishment tabular data. Journal of Official Statistics 14, 537-551 
Fernald, John G., (2014) "Productivity and Potential Output Before, During, and After the Great Recession." In NBER Macroeconomics Annual 2014, Volume 29, eds Jonathan A. Parker \& Michael Woodford, 2015, NBER Books,

National Bureau of Economic Research, Cambridge, Massachusetts.

Fort, Teresa and Shawn D. Klimek (2014), "Detailed Methodology for the FortKlimek NAICS codes,” mimeo, Tuck School of Business at Dartmouth

Fujita, M., Krugman, P. R., \& Venables, A. (2001). The spatial economy: Cities, regions, and international trade. MIT press.

Graham, S., Grim, C., Islam, T., Marco, A., \& Miranda, J. (2014). Business Dynamics of Innovating Firms: Linking U.S. Patents with Administrative Data on Workers and Firms. Available at SSRN 2637602.

Haltiwanger, J., Hathaway, I., \& Miranda, J. (2014). Declining business dynamism in the US high-technology sector. Available at SSRN 2397310.

Hathaway, I. (2013). Tech starts: High-technology business formation and job creation in the United States. Ewing Marion Kauffman Foundation Research Paper.

Hatzichronoglou, T. (1997), "Revision of the High-Technology Sector and Product Classification", OECD Science, Technology and Industry Working Papers, No. 1997/02. doi: 10.1787/134337307632

Hecker, D. (1999). High-technology employment: a broader view. Monthly Lab. Rev., $122,18$.

Heckler, D. (2005). High-technology employment: a NAICS-based update. Monthly Lab. Rev., 128, 57.

Kask, C., \& Sieber, E. (2002). Productivitiy Growth in High-Tech Maufacturing Industries. Monthly Lab. Rev., 125, 16.

Jarmin, R., Louis, T., \& Miranda, J. (2014). "Expanding the Role of Synthetic Data at the U.S. Census Bureau." J. Intl. Association for Official Statistics, 30: 117-121. 
Jarmin, R. S., \& Miranda, J. (2002). The longitudinal business database. Available at SSRN 2128793.

Jorgenson, D. W., Ho, M. S., \& Stiroh, K. J. (2002). Projecting productivity growth: lessons from the US growth resurgence (Vol. 20036). Washington, DC.

Jorgenson, D. W., Ho, M. S., \& Stiroh, K. J. (2008). A retrospective look at the US productivity growth resurgence. The Journal of Economic Perspectives, 22(1), 3-24.

NSF (2002) Science and Engineering Indicators.

NSF (2003) Science and Engineering Indicators. (chapter 8)

NSF (2010) Science and Engineering Indicators.

Organisation for Economic Co-operation and Development (OECD). 2001.

Knowledge-Based Industries. Paris: Directorate for Science, Technology, and Industry/Economic Analysis Statistics.

Organisation for Economic Co-operation and Development (OECD). 2002. Frascati Manual: Proposed Standard Practice for Surveys on Research and Experimental Development, 6th edition.

Organisation for Economic Co-operation and Development (OECD). 2003. Science, Technology and Industry Scoreboard 2003, Annex 1.

Organisation for Economic Co-operation and Development (OECD). 2007. Science, Technology and Industry Scoreboard 2007, Annex 1. Paris: Directorate for Science, Technology, and Industry. http://masetto.sourceoecd.org/pdf/sti2007/922007081e1annex1.pdf. Accessed 26 June 2009.

Organisation for Economic Co-operation and Development (OECD). (2010), Measuring Innovation: A New Perspective, OECD Publishing, Paris.

Organisation for Economic Co-operation and Development (OECD). 2015a. Science, Technology and Industry Scoreboard 2015. 
Organisation for Economic Co-operation and Development (OECD). 2015b. The R\&D Intensity of Economic Activities in OECD Countries: Proposal for a New Classification for Industry and Services. Directorate for Science, Technology and Innovation; Committee for Scientific and Technology Policy.

Schumpeter, Joseph (1942). Capitalism, Socialism, and Democracy. New York: Harper.

Sichel, D. E., \& Oliner, S. D. (2002). Information technology and productivity: where are we now and where are we going?. Board of Governors of the Federal Reserve System FEDS, 29.

Stoneman, P., \& Battisti, G. (2010). The diffusion of new technology. Handbook of the Economics of Innovation, 2, 733-760. 


\section{TABLES AND FIGURES}

Table 1. Methodologies of Identifying High Tech Industries

\begin{tabular}{ll}
\hline Method & Literature \\
\hline Inputs Based & \\
\hline $\begin{array}{l}\text { STEM and R\&D } \\
\text { Employment }\end{array}$ & Hecker (1999), Hecker (2005), Hathaway (2013), Haltiwanger, \\
\hline $\begin{array}{l}\text { R\&D Intensity (direct and } \\
\text { indirect) }\end{array}$ & Hathaway, \& Miranda (2014) \\
\hline $\begin{array}{l}\text { Output Based } \\
\text { Production of High Tech }\end{array}$ & NSF (2002), Hatzichronoglou (1997) \\
Products & \\
\hline
\end{tabular}

Table 2. Example High-Tech Occupations

\begin{tabular}{ll}
\hline SOC Code & Occupations \\
\hline \multicolumn{2}{l}{ Computer and Math Sciences } \\
\hline $11-3020$ & Computer and information systems managers \\
\hline 15-0000 & Computer and mathematical scientists \\
\hline Engineering and related \\
\hline $11-9040$ & Engineering managers \\
\hline $17-2000$ & Engineers \\
\hline $17-3000$ & Drafters, engineering, and mapping technicians \\
\hline Physical and Life Sciences \\
\hline $11-9120$ & Natural sciences managers \\
\hline $19-1000$ & Life scientists \\
\hline $19-2000$ & Physical scientists \\
\hline $19-4000$ & Life, physical, and social science technicians \\
\hline Source: Hathaway (2013), Bureau of Labor Statistics. \\
Notes: For full list, see Table 3 in Hecker (2005).
\end{tabular}

Table 3. Number Industries by Vintage and Group

\begin{tabular}{|c|c|c|c|}
\hline & \multicolumn{3}{|c|}{ Vintage } \\
\hline Group & Hecker (2005) & STEM 2012 & STEM 2014 \\
\hline Level I & 55 & 50 & 52 \\
\hline Level II & 58 & 54 & 60 \\
\hline Level III & 60 & 63 & 59 \\
\hline Total & 173 & 167 & 171 \\
\hline $\begin{array}{l}\text { Source: Heck } \\
\text { and } 2014 \text { inc } \\
\text { Notes: All co } \\
\text { industries w } \\
\text { converted to }\end{array}$ & $\begin{array}{l}005) \text { and recalculated } \\
y^{-o c c u p a t i o n ~ e m p l o y m ~} \\
\text { are of } 6 \text {-digit } 2007 \mathrm{NA} \\
\text { and } 4 \text {-digit } 2007 \mathrm{NAI} \\
\text { it industries for comp }\end{array}$ & $\begin{array}{l}\text { TEM concentratiol } \\
\text { at matrices. } \\
\text { CS industries. Orig } \\
\text { S industries. These } \\
\text { ability. }\end{array}$ & $\begin{array}{l}\text { using BLS } 2012 \\
\text { al Hecker (2005) } \\
\text { ave been }\end{array}$ \\
\hline
\end{tabular}


Table 4. Number of Industries Overlapping and Exclusive to each Vintage

\begin{tabular}{lc}
\hline & Industries \\
\hline All 3 Years & 147 \\
\hline Hecker (2005) Only & 24 \\
\hline STEM 2012 Only & 1 \\
\hline STEM 2014 Only & 7 \\
\hline Combination of Two Years (Residual) & 198 \\
\hline Total & 198 \\
\hline $\begin{array}{l}\text { Notes: Includes counts of 6-digit 2007 NAICS industries associated with different } \\
\text { combinations of High Tech methodologies. The total captures the count of unique } \\
\text { industries across all three vintages. For a detailed list of industries only appearing } \\
\text { in 2012 and 2014 see Appendix F. The residual category captures all industries } \\
\text { that are observed in some combination of two years-2005, 2012, and 2014. We } \\
\text { include the residual category for completeness. }\end{array}$
\end{tabular}

Table 5. Number Industries Overlapping and Exclusive by Vintage and Group

\begin{tabular}{lccc}
\hline & Level I & Level II & Level III \\
\hline All 3 Years & 48 & 32 & 27 \\
\hline Hecker (2005) Only & 6 & 7 & 26 \\
\hline STEM 2012 Only & 2 & 4 & 11 \\
\hline STEM 2014 Only & 3 & 5 & 14 \\
\hline
\end{tabular}

Notes: Includes counts of 6-digit 2007 NAICS industries associated with different combinations of High Tech vintages. 
Table 6. High Tech Industry Counts by Major Sector and Methodology

\begin{tabular}{|c|c|c|c|c|c|c|}
\hline Major Sector & $\begin{array}{l}\text { Hecker } \\
(2005)\end{array}$ & $\begin{array}{l}\text { STEM } \\
2012\end{array}$ & $\begin{array}{c}\text { STEM } \\
2014\end{array}$ & $\begin{array}{l}\text { Census } \\
\text { ATP }\end{array}$ & $\begin{array}{l}\text { OECD } \\
(2003)\end{array}$ & $\begin{array}{l}\text { OECD } \\
(2015)\end{array}$ \\
\hline $\begin{array}{l}\text { Agriculture, } \\
\text { Forestry, Fishing } \\
\text { and Hunting }\end{array}$ & 2 & . & . & . & . & . \\
\hline $\begin{array}{l}\text { Arts \& } \\
\text { Accommodation }\end{array}$ & $\cdot$ & . & . & . & 1 & . \\
\hline Construction & . & . & . & . & . & . \\
\hline Education \& Health & . & . & . & . & 2 & . \\
\hline FIRE & 2 & 8 & 7 & . & 50 & . \\
\hline Information & 8 & 11 & 11 & 1 & 14 & 2 \\
\hline $\begin{array}{l}\text { Management \& } \\
\text { Support }\end{array}$ & 5 & 3 & 3 & . & 27 & . \\
\hline Manufacturing & 111 & 106 & 105 & 90 & 133 & 236 \\
\hline Mining \& Utilities & 8 & 8 & 15 & . & 4 & . \\
\hline Retail \& Wholesale & 7 & 7 & 7 & . & . & . \\
\hline Services & 26 & 22 & 22 & 7 & 57 & 8 \\
\hline $\begin{array}{l}\text { Transport \& } \\
\text { Warehousing }\end{array}$ & 4 & 2 & 1 & . & 5 & . \\
\hline Total & 173 & 167 & 171 & 98 & 293 & 246 \\
\hline $\begin{array}{l}\text { Notes: Counts are of } 6 \text {-digit } \\
\text { show counts of industries for } \\
\text { classified as high and mediu } \\
\text { Technology industries. Since } \\
\text { shows the employment share }\end{array}$ & $\begin{array}{l}007 \text { NAICS } \\
\text { all three leve } \\
\text {-High Tech } \\
\text { not all major }\end{array}$ & $\begin{array}{l}\text { dustries. F } \\
\text { s of High T } \\
\text { ology and fo } \\
\text { sectors hav }\end{array}$ & Hecker & $\begin{array}{l}\text { 5), STEM } 2 \\
\text { For OECD ( } \\
\text { we use hi\& } \\
\text { nber of indu }\end{array}$ & $\begin{array}{l}12, \text { and ST } \\
003) \text { we us } \\
\text { and medi } \\
\text { stries, Appe }\end{array}$ & $\begin{array}{l}\text { M } 2014 \\
\text { ndustries } \\
\text { n-High } \\
\text { dix G }\end{array}$ \\
\hline
\end{tabular}




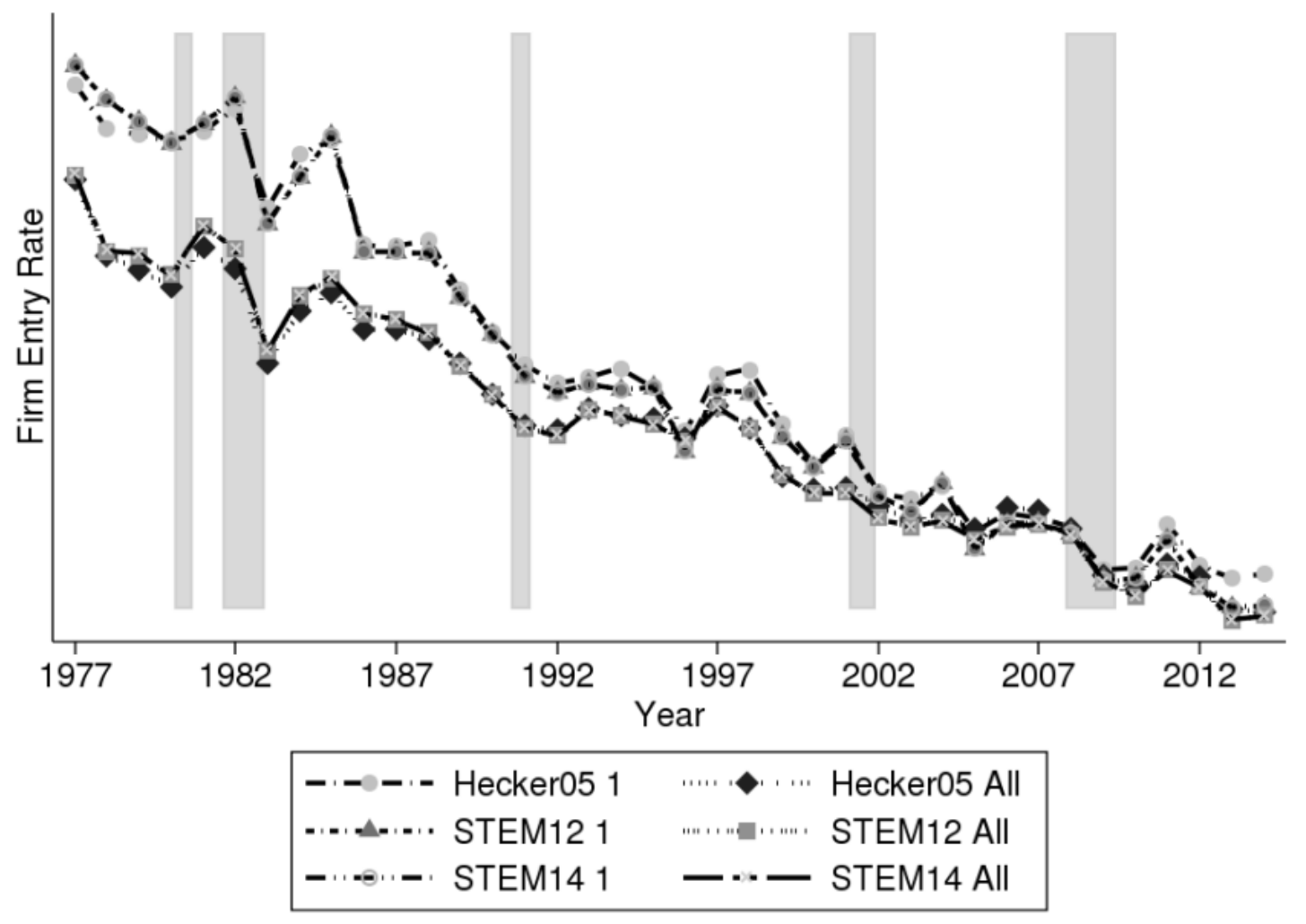

Figure 1. Manufacturing High Tech —Firm Entry Rates. STEM based definitions.

Source: Longitudinal Business Database, author's calculations.

Notes: Hecker05 1, STEM12 1, and STEM14 1 capture Level I industries according to Hecker 2005, STEM 2012, and STEM 2014 respectively. Hecker05 All, STEM12 All, and STEM14 All capture industries in all 3 levels according to Hecker 2005, STEM 2012, and STEM 2014 respectively. Firm entry rate calculated as 100 * the count of age zero firms at time t divided by the average number of firms in in time $t$ and $t-1$. The $y$-axis has been removed to avoid the disclosure of sensitive data. Shaded regions represent recessions as defined by NBER. 


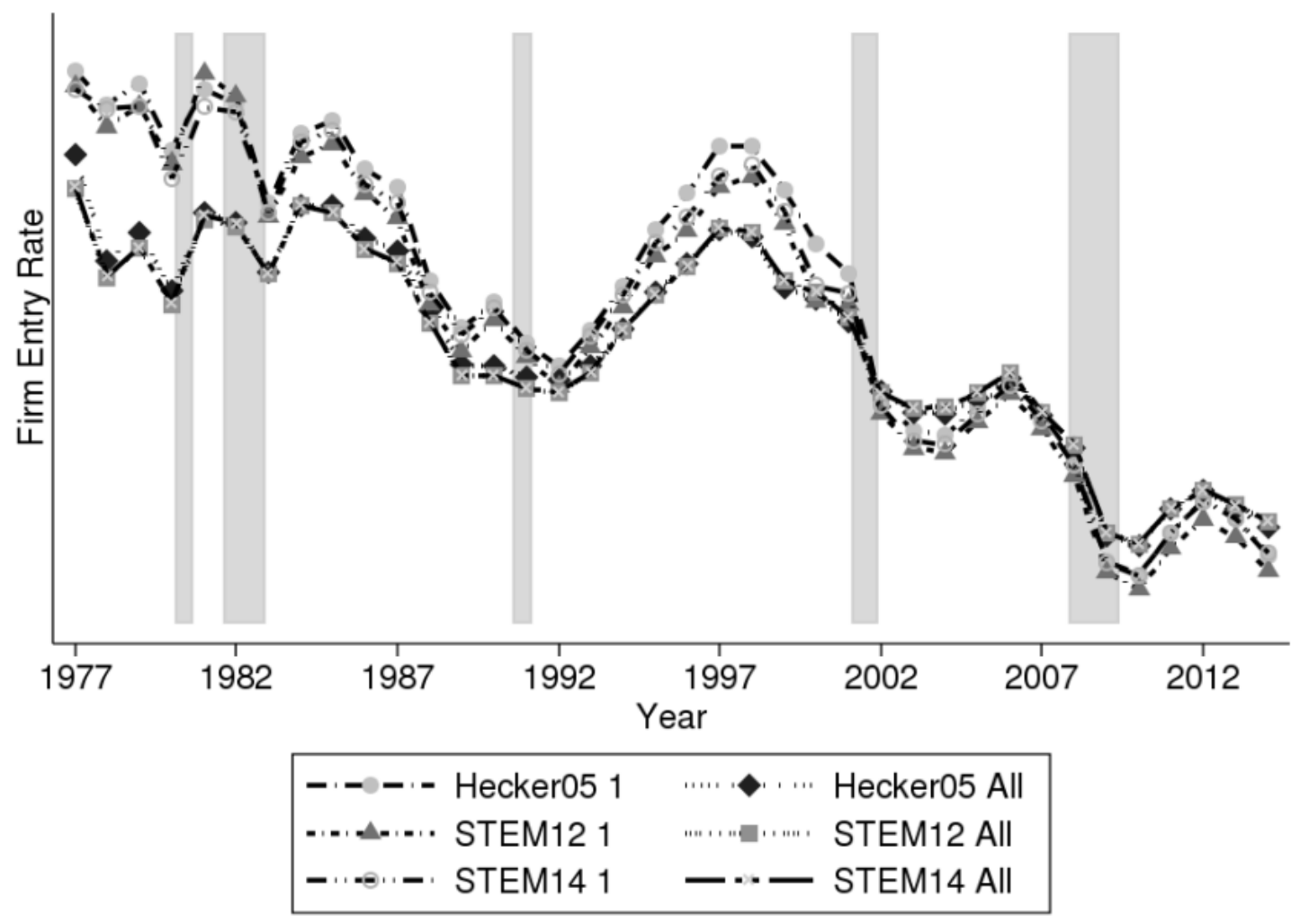

Figure 2. All High Tech —Firm Entry Rates. STEM based definitions.

Source: Longitudinal Business Database, author's calculations.

Notes: Hecker05 1, STEM12 1, and STEM14 1 capture Level I industries according to Hecker 2005, STEM 2012, and STEM 2014 respectively. Hecker05 All, STEM12 All, and STEM14 All capture industries in all 3 levels according to Hecker 2005, STEM 2012, and STEM 2014 respectively. Firm entry rate calculated as 100 * the count of age zero firms at time $t$ divided by the average number of firms in in time $t$ and $t-1$. The $\mathrm{y}$-axis has been removed to avoid the disclosure of sensitive data. Shaded regions represent recessions as defined by NBER. 


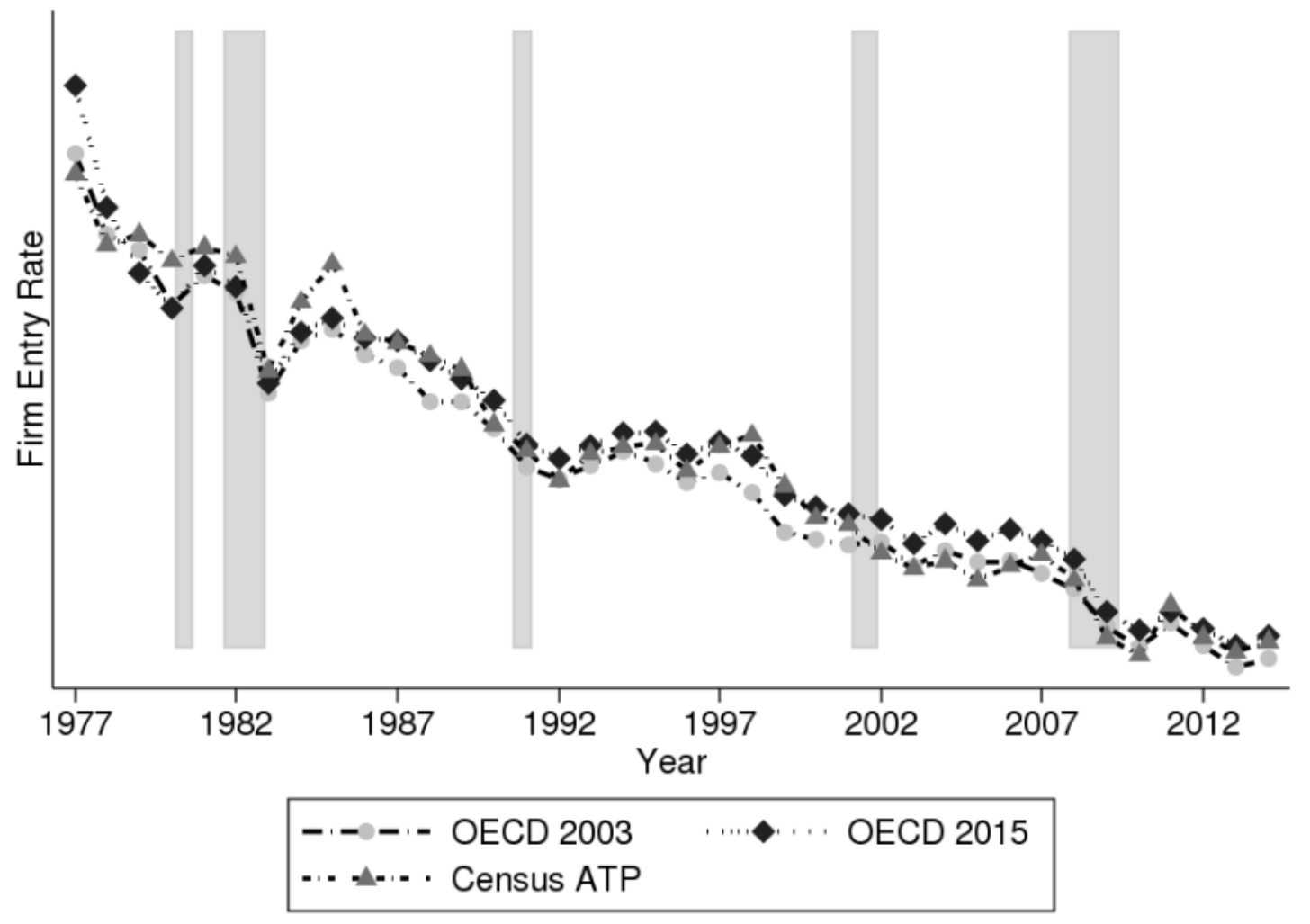

Figure 3. Manufacturing High Tech -Firm Entry Rates. OECD and Census ATP definitions.

Source: Longitudinal Business Database, author's calculations.

Notes: Firm entry rate calculated as $100^{*}$ the count of age zero firms at time $t$ divided by the average number of firms in in time $t$ and $t-1$. The y-axis has been removed to avoid the disclosure of sensitive data. Shaded regions represent recessions as defined by NBER. 


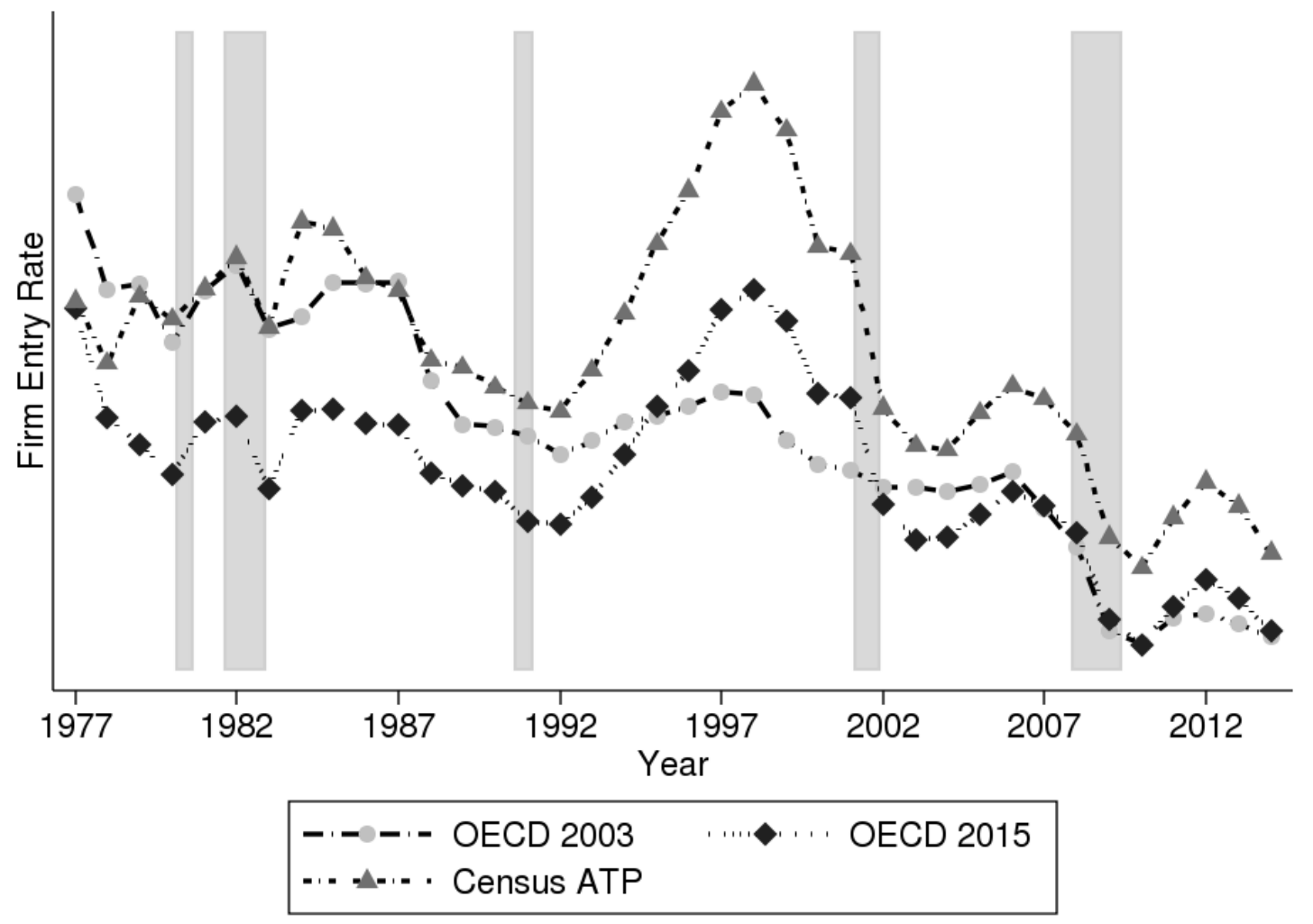

Figure 4. All High Tech —Firm Entry Rates. OECD and Census ATP definitions.

Source: Longitudinal Business Database, author's calculations.

Notes: Firm entry rate calculated as $100 *$ the count of age zero firms at time $t$ divided by the average number of firms in in time $t$ and $t$-1. The y-axis has been removed to avoid the disclosure of sensitive data. Shaded regions represent recessions as defined by NBER. 


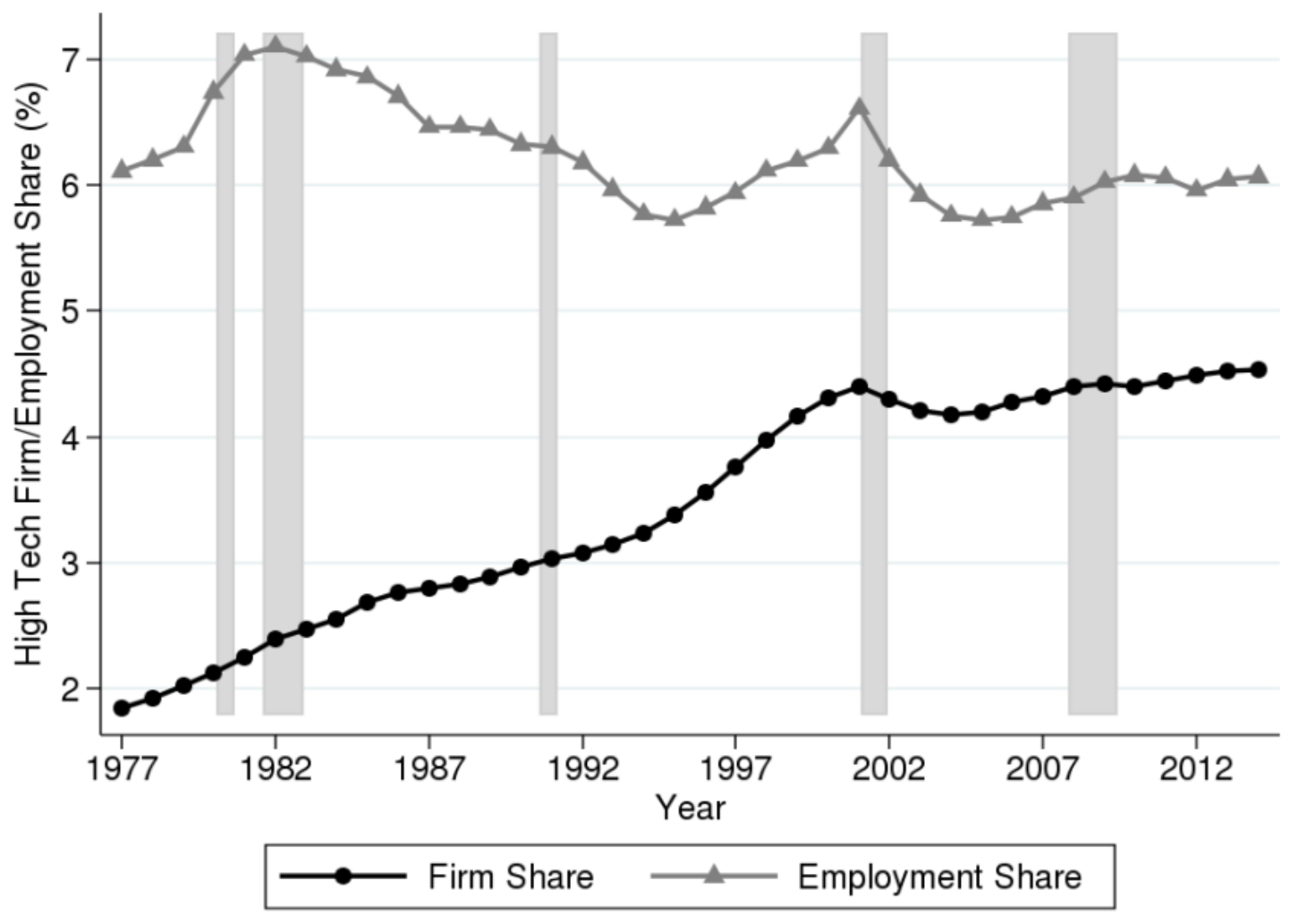

Figure 5. High Tech Firm and Employment Share

Source: BDS High Tech, author's calculations.

Notes: Y-axis does not start at zero. Firm share is calculated as the number of firms with at least one establishment in a High Tech industry divided by the total number of firms in the economy. Employment share is calculated as the sum of employment at High Tech establishments divided by the total amount of employment in the economy. Shaded regions represent recessions as defined by NBER. 


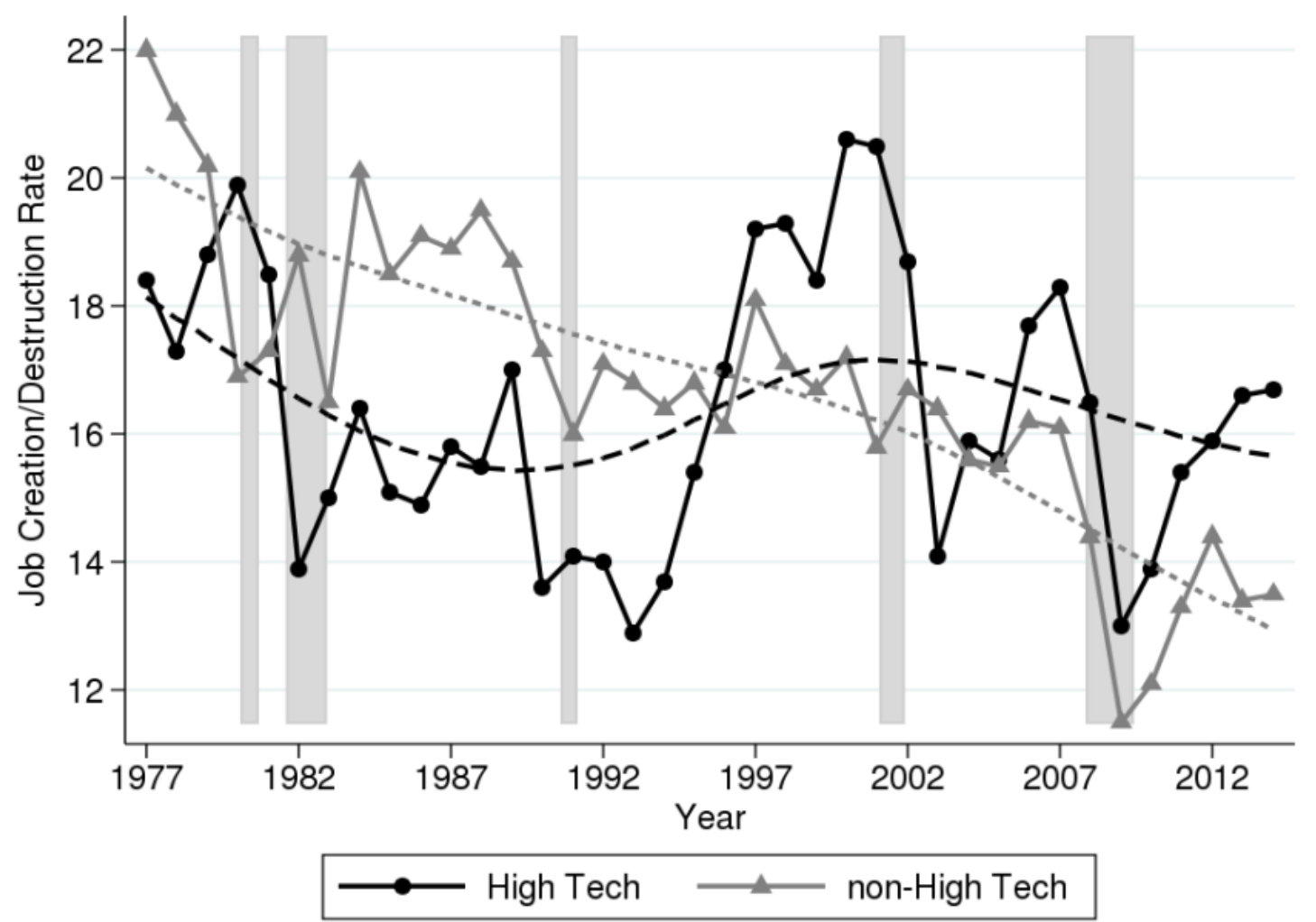

Figure 6. Job Creation Rates in High Tech and non-High Tech Industries Source: BDS High Tech, author's calculations.

Notes: Trends calculated by applying a Hodrick-Prescott filter with a multiplier of 400. Y-axis does not start at zero. Shaded regions represent recessions as defined by NBER. 


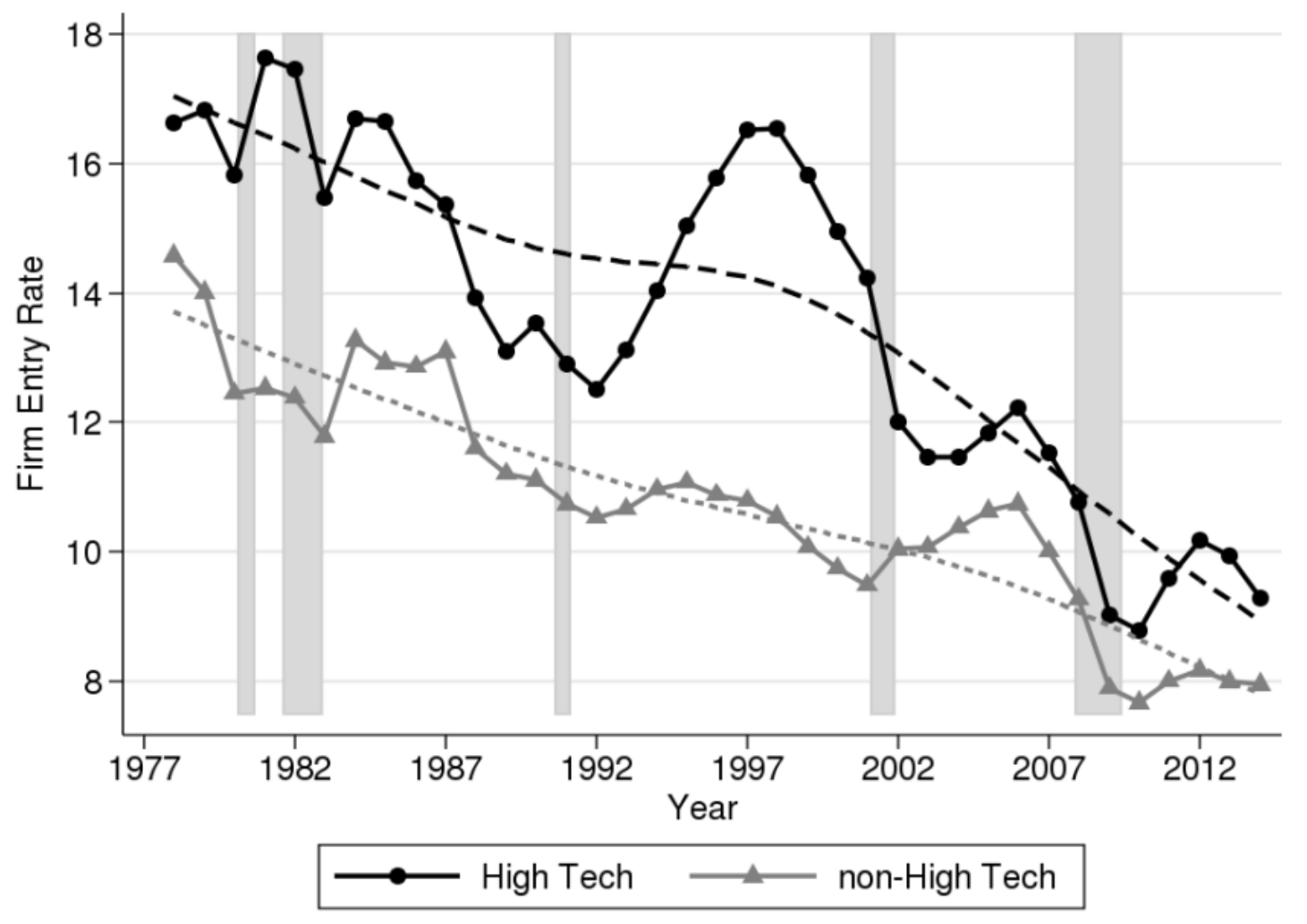

Figure 7. Firm Entry Rate High Tech vs non-High Tech

Source: BDS High Tech, author's calculations.

Notes: Trends calculated by applying a Hodrick-Prescott filter with a multiplier of 400. Firm Y-axis does not start at zero.

Firm entry rate calculated as the count of age zero firms in year $t$ divided by the average count of firms in year $t$ and $t-1$.

Shaded regions represent recessions as defined by NBER. 


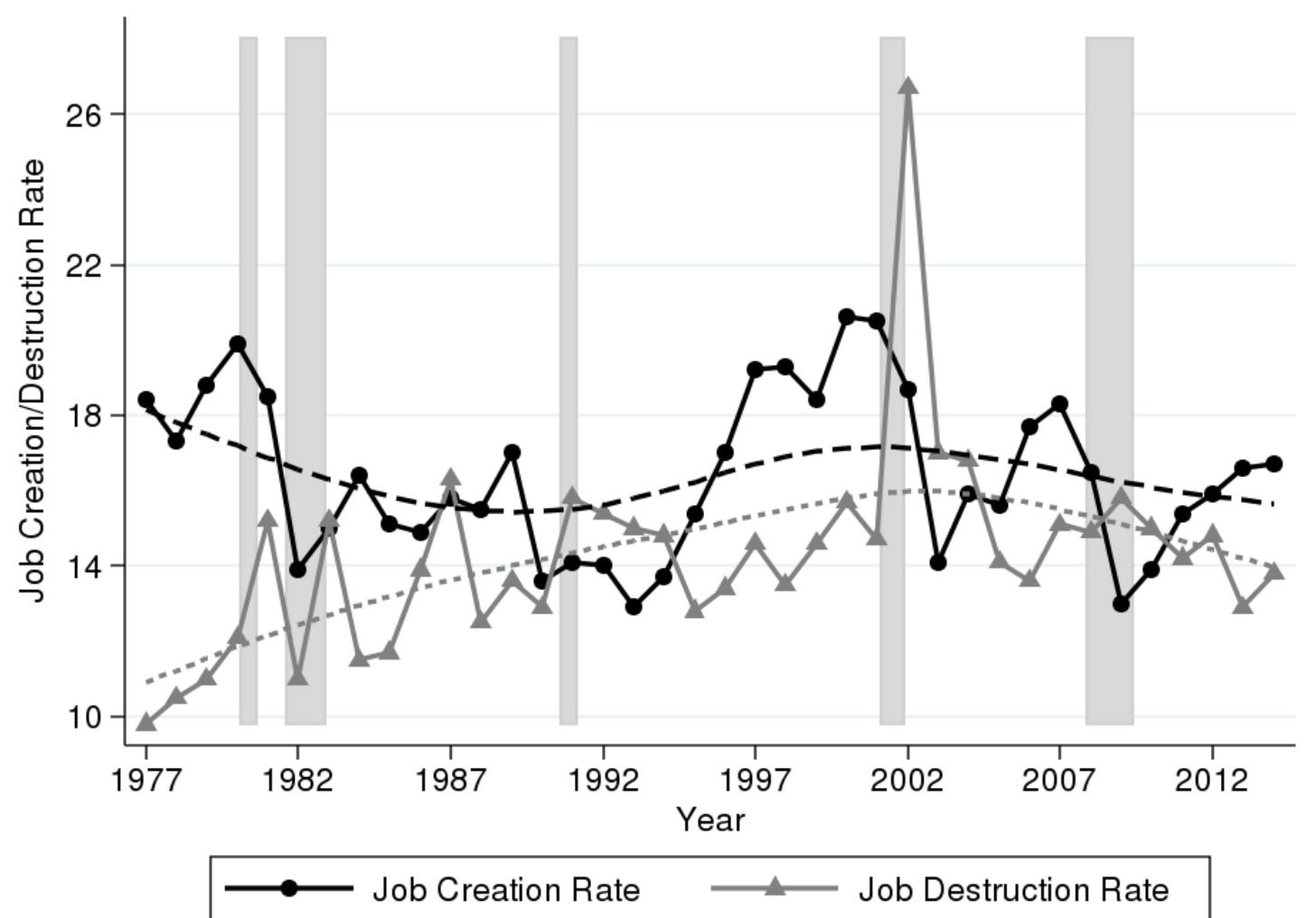

Figure 8. High Tech Job Creation Rate and Job Destruction Rate Source: BDS High Tech, author's calculations. Notes: Trends calculated by applying a Hodrick-Prescott filter with a multiplier of 400. Firm Y-axis does not start at zero. Firm entry rate calculated as the count of age zero firms in year t divided by the average count of firms in year $t$ and $t-1$. Shaded regions represent recessions as defined 


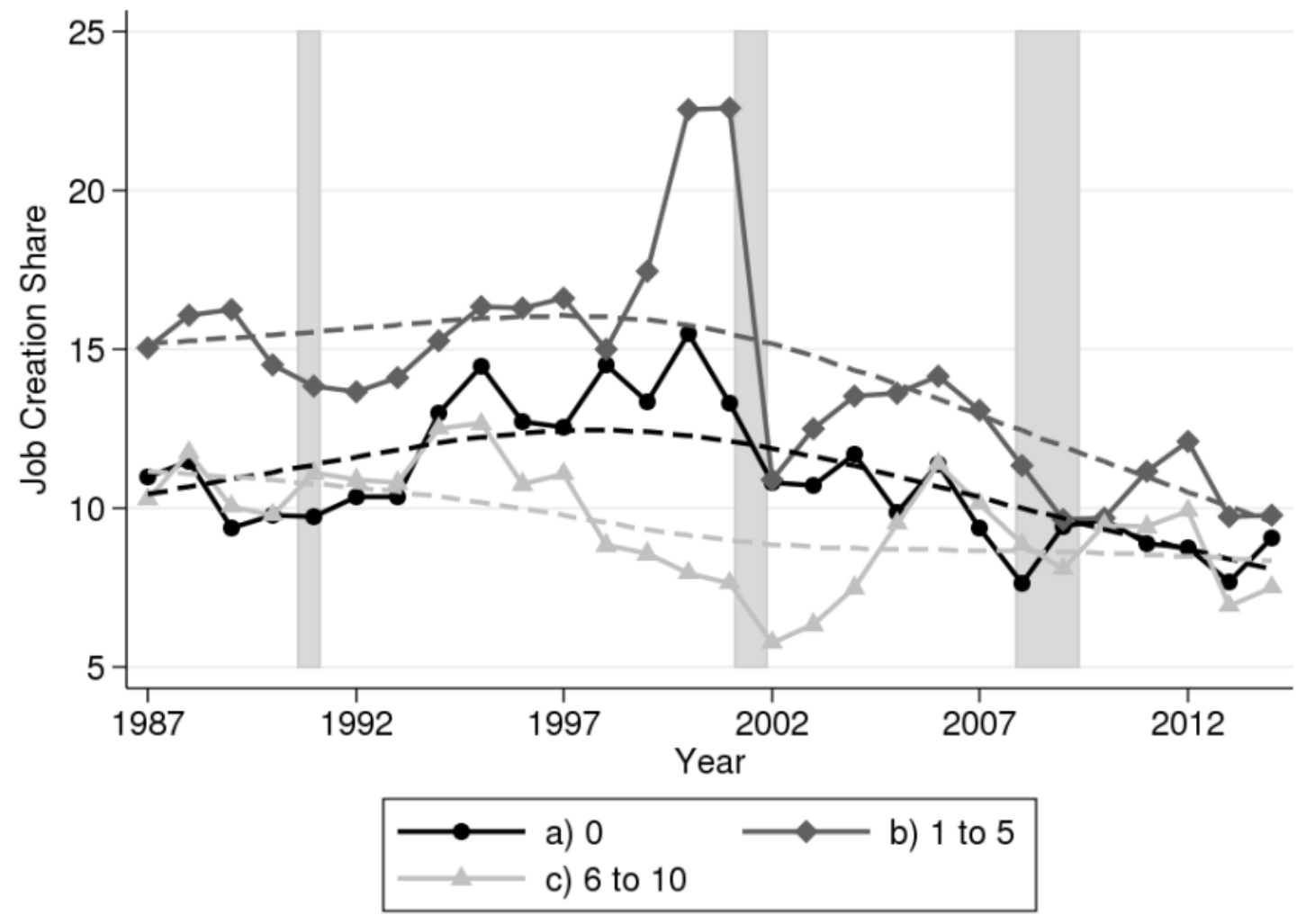

Figure 9. Job Creation Share by Firm Age

Source: BDS High Tech, author's calculations.

Notes: Trends calculated by applying a Hodrick-Prescott filter with a multiplier of 400. Y-axis does not start at zero. Shaded regions represent recessions as defined by NBER. 


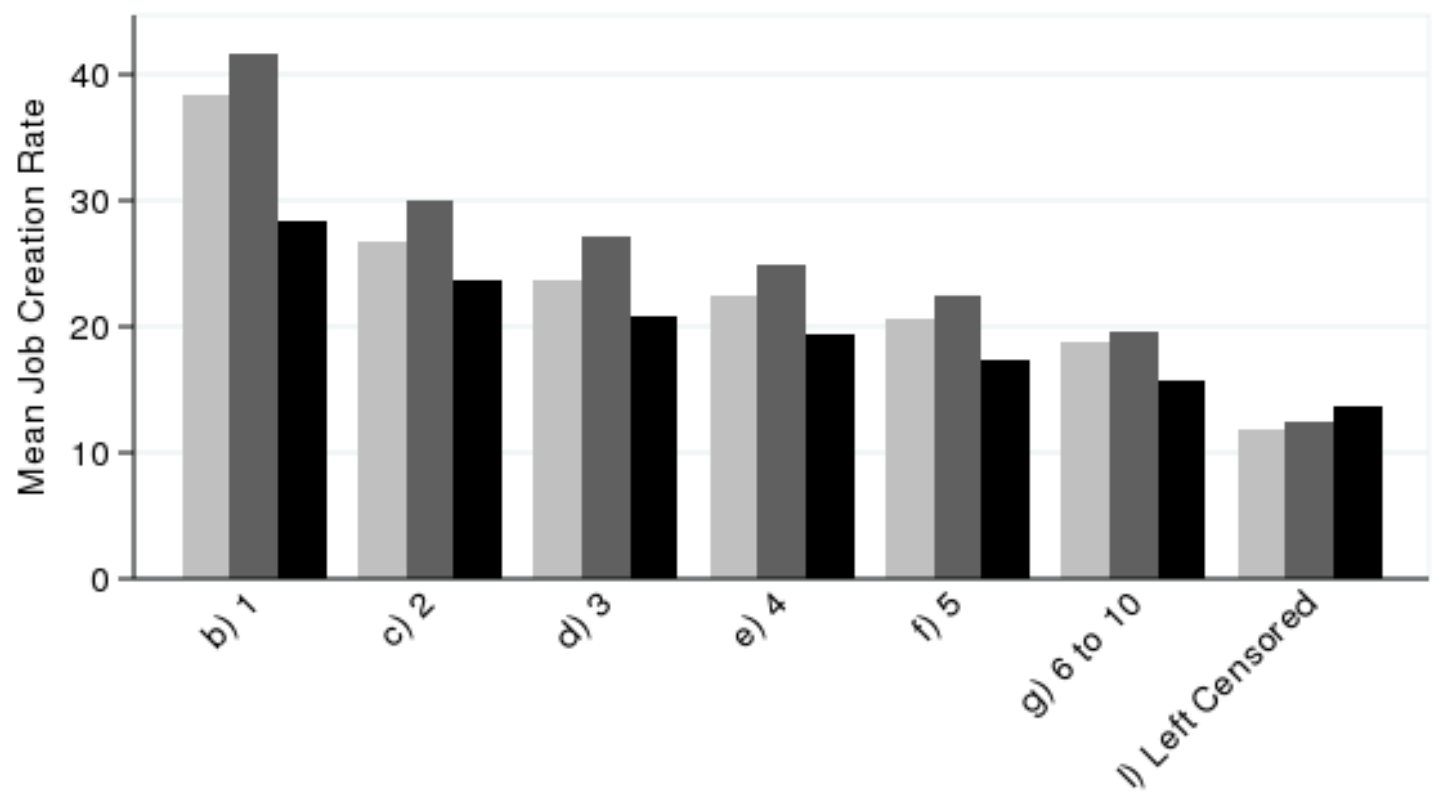

Firm Age

\begin{tabular}{|l|l|}
\hline 1983 to 1992 & 1993 to 2001 \\
2002 to 2014 & \\
\hline
\end{tabular}

Figure 10. Average High Tech Job Creation Rates over time - By Firm Age Source: BDS High Tech, author's calculations. 


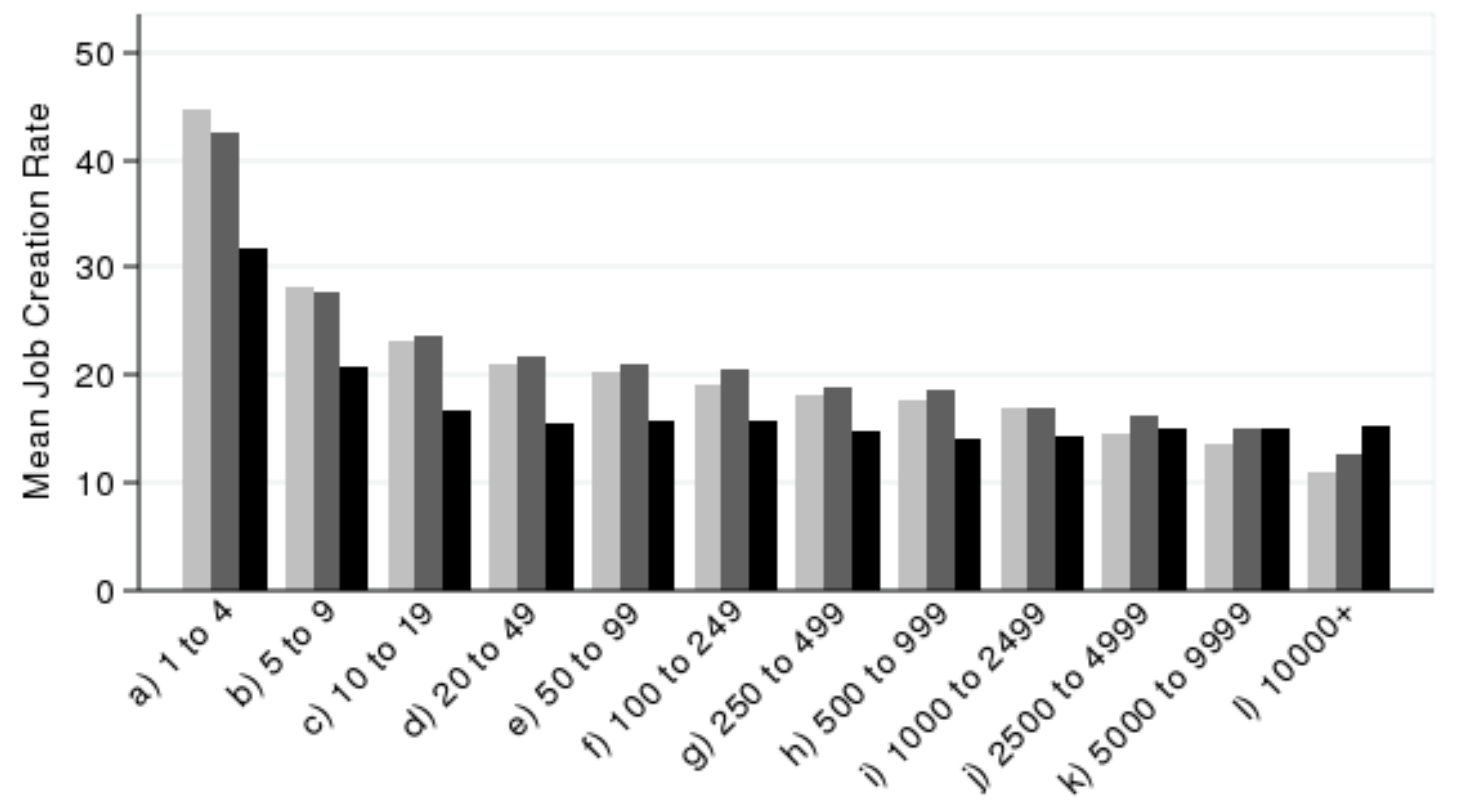

Firm Size

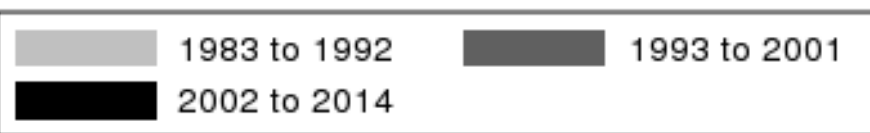

Figure 11. Average High Tech Job Creation Rates over time - By Firm Size Source: BDS High Tech, author's calculations. 

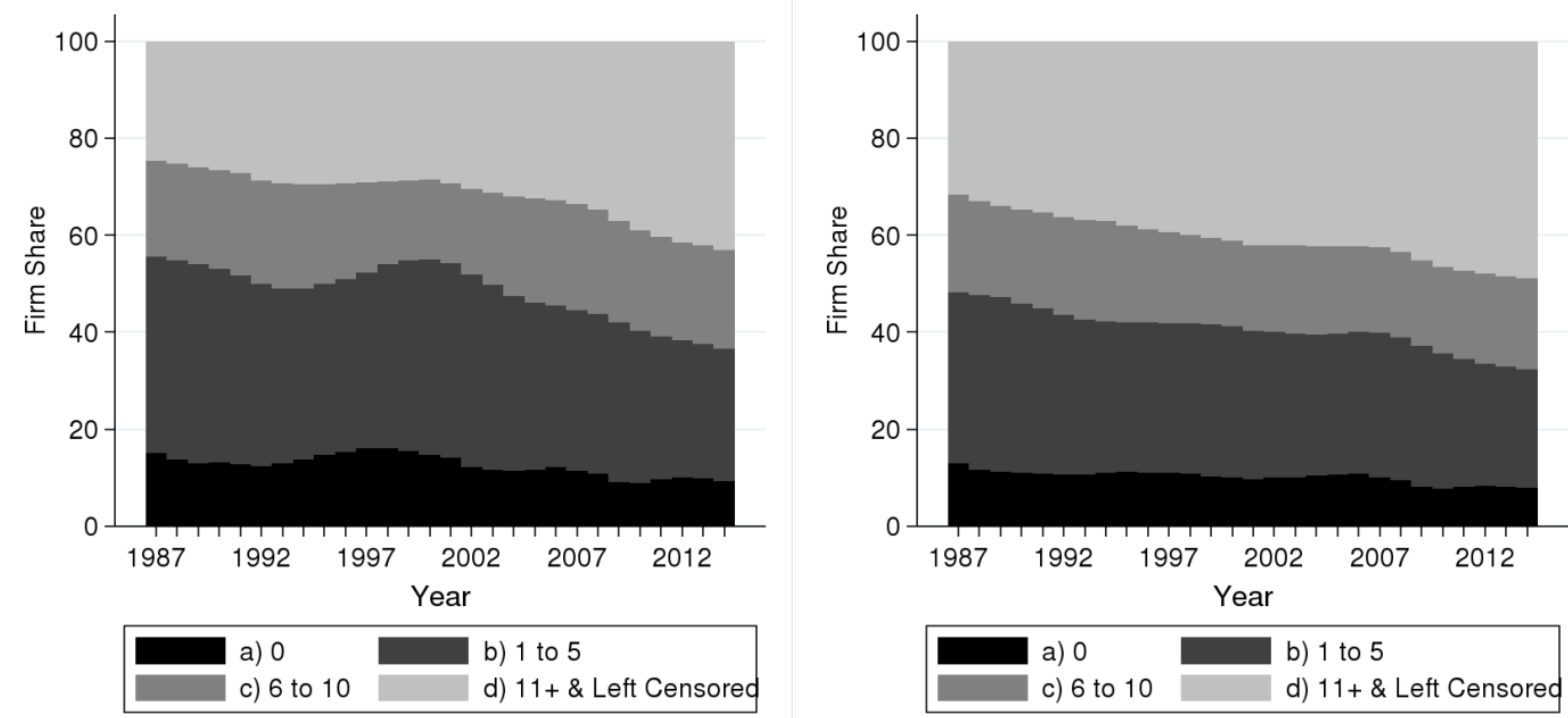

Figure 12: Firm Share by Firm Age for High Tech (left) and non-High Tech Sector (right) Source: BDS High Tech, author's calculations. The x-axis begins at 1987 because this is the first year we observe firms in all of the listed age categories.
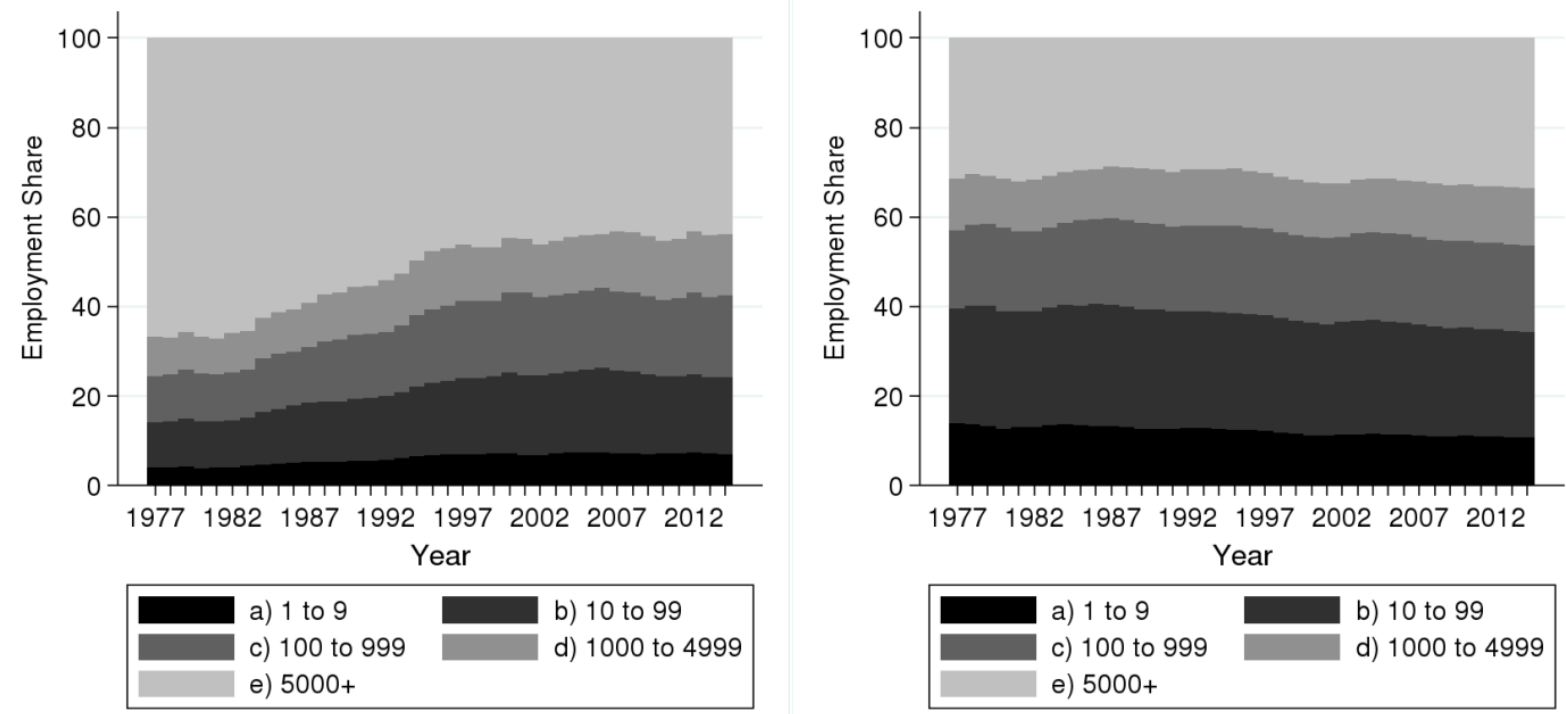

Figure 13: Employment Share by Firm Size for High Tech (left) and non-High Tech Sector (right)

Source: BDS High Tech, author's calculations. 

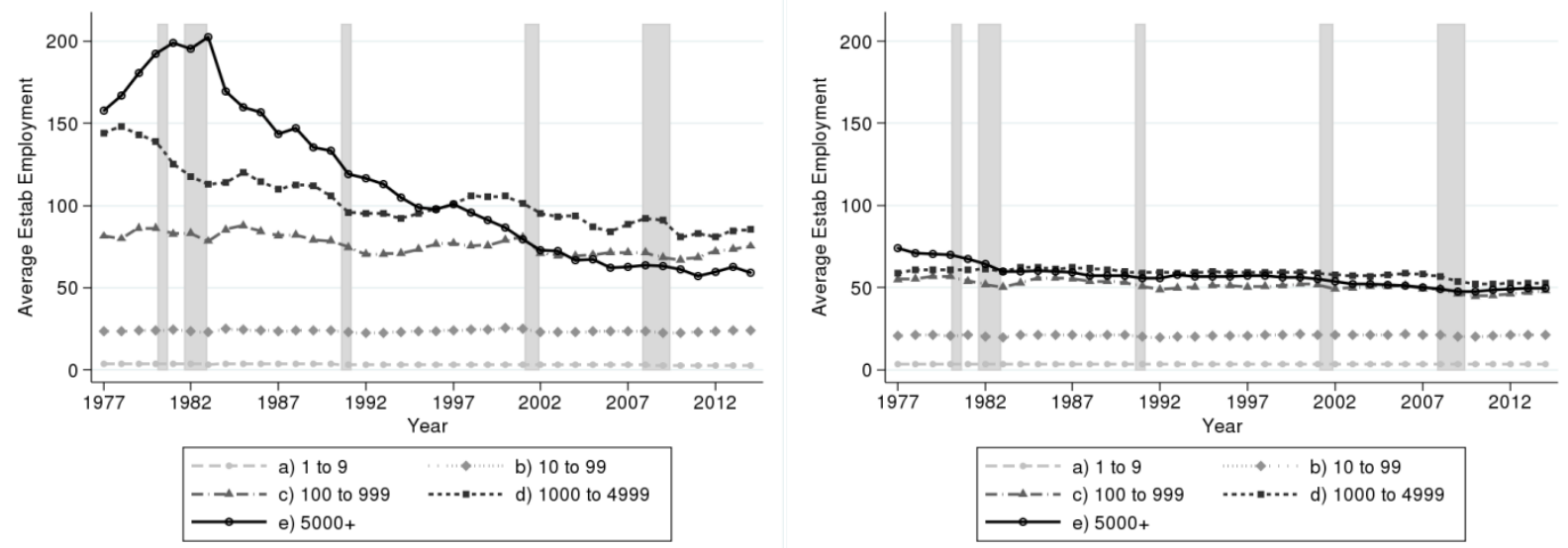

Figure 14: Average Establishment Size by Firm Size, High Tech (left) and non-High Tech (right)

Source: BDS High Tech, author's calculations. Average establishment employment is calculated as the sum of employment in a cell divided by the total count of establishments within that cell. Shaded regions represent recessions as defined by NBER. 


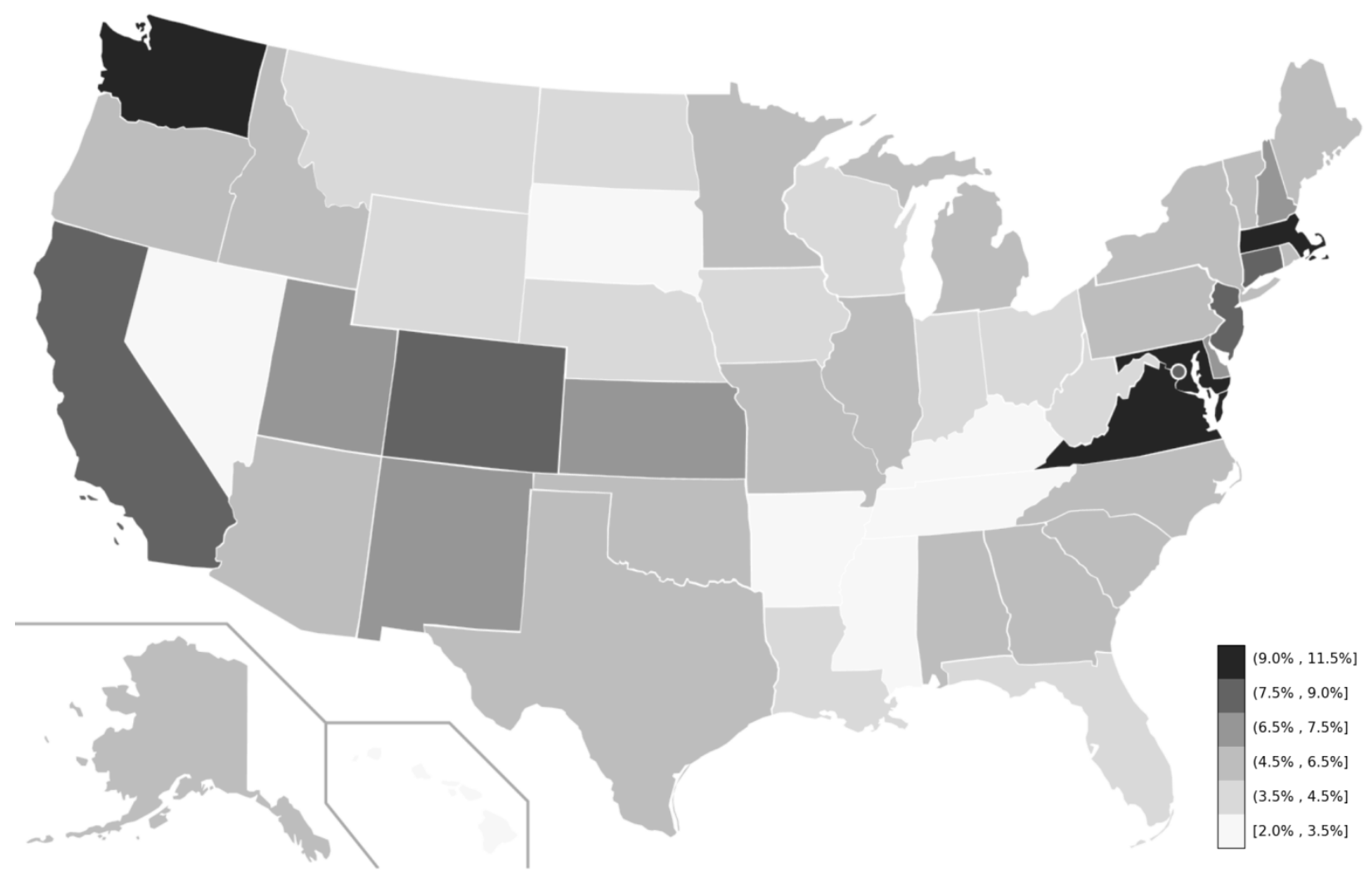

Figure 15. Average High Tech Employment Share by State, 2012-2014

Source: BDS High Tech, author's calculations. 
APPENDIX A. HIGH TECH INDUSTRIES ACCORDING TO HECKER (2005)

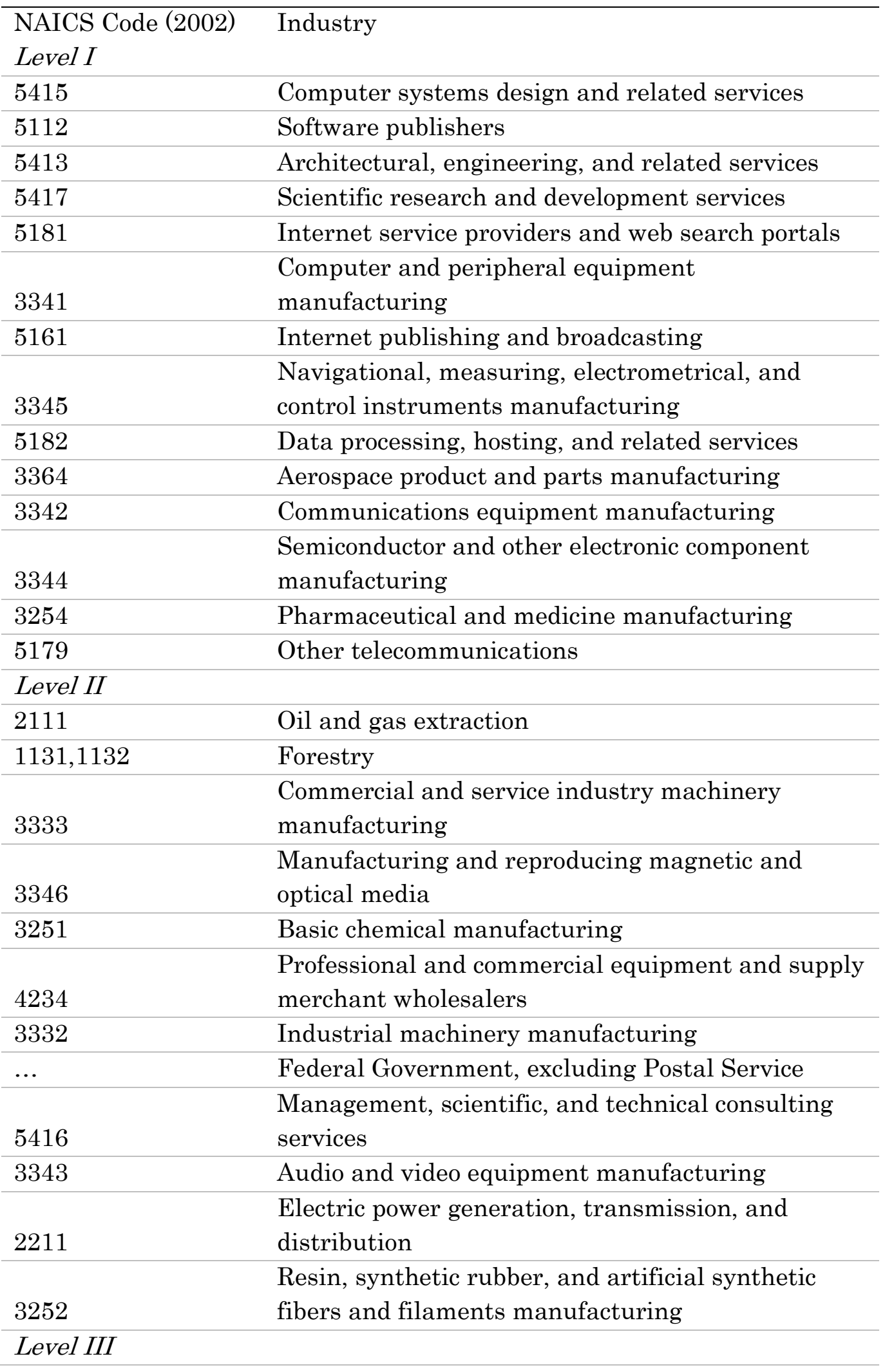




\begin{tabular}{|c|c|}
\hline 5171 & Wired telecommunications carriers \\
\hline 5511 & Management of companies and enterprises \\
\hline 4862 & Pipelines transportation of natural gass \\
\hline 5211 & Monetary authorities — central bank \\
\hline 5172 & $\begin{array}{l}\text { Wireless telecommunications carriers (except } \\
\text { satellite) }\end{array}$ \\
\hline 5173 & Telecommunications resellers \\
\hline 5174 & Satellite telecommunications \\
\hline 3353 & Electrical equipment manufacturing \\
\hline 3259 & $\begin{array}{l}\text { Other chemical product and preparation } \\
\text { manufacturing }\end{array}$ \\
\hline 3339 & Other genera-purpose machinery manufacturing \\
\hline 3336 & $\begin{array}{l}\text { Engine, turbine, and power transmission } \\
\text { equipment manufacturing }\end{array}$ \\
\hline 3255 & Paint, coating, and adhesive manufacturing \\
\hline 3241 & Petroleum and coal products manufacturing \\
\hline 8112 & $\begin{array}{l}\text { Electronic and precision equipment repair and } \\
\text { maintenance }\end{array}$ \\
\hline 5612 & Facilities support services \\
\hline 3253 & $\begin{array}{l}\text { Pesticides, fertilizer, and other agricultural } \\
\text { chemical manufacturing }\end{array}$ \\
\hline 5232 & Securities and commodity exchanges \\
\hline 4861 & Pipeline transportation crude oil \\
\hline 3369 & Other transportation equipment manufacturing \\
\hline 4869 & Other pipeline transportation \\
\hline
\end{tabular}


APPENDIX B. HIGH TECH INDUSTRIES ACCORDING TO HECKER (1999)

\begin{tabular}{|c|c|}
\hline NAICS Code (1997) & Industry \\
\hline 32411 & Petroleum refineries \\
\hline 3251 & Basic chemical manufacturing \\
\hline 3252 & $\begin{array}{l}\text { Resin, synthetic rubber, and artificial and synthetic fibers and } \\
\text { filaments manufacturing }\end{array}$ \\
\hline 3253 & Pesticide, fertilizer, and other agricultural chemical manufacturing \\
\hline 3254 & Pharmaceutical and medicine manufacturing \\
\hline 3255 & Paint, coating, and adhesive manufacturing \\
\hline 3256 & Soap, cleaning compound, and toilet preparation manufacturing \\
\hline 3259 & Other chemical product and preparation manufacturing \\
\hline 332992 & $\begin{array}{l}\text { Ordnance \& accessories manufacturing—-small arms ammunition } \\
\text { manufacturing }\end{array}$ \\
\hline 332993 & $\begin{array}{l}\text { Ordnance \& accessories manufacturing-ammunition (except small } \\
\text { arms) manufacturing }\end{array}$ \\
\hline 332994 & $\begin{array}{l}\text { Ordnance \& accessories manufacturing—small arms } \\
\text { manufacturing }\end{array}$ \\
\hline 332995 & $\begin{array}{l}\text { Ordnance \& accessories manufacturing—other ordnance and } \\
\text { accessories manufacturing }\end{array}$ \\
\hline 3331 & Agriculture, construction, and mining machinery manufacturing \\
\hline 3332 & Industrial machinery manufacturing \\
\hline 3333 & Commercial and service industry machinery manufacturing \\
\hline 3336 & Engine, turbine, and power transmission equipment manufacturing \\
\hline 3339 & Other general purpose machinery manufacturing \\
\hline 3341 & Computer and peripheral equipment manufacturing \\
\hline 3342 & Communications equipment manufacturing \\
\hline 3343 & Audio and video equipment manufacturing \\
\hline 3344 & Semiconductor and other electronic component manufacturing \\
\hline 3345 & $\begin{array}{l}\text { Navigational, measuring, electromedical, and control instruments } \\
\text { manufacturing }\end{array}$ \\
\hline 3346 & Manufacturing and reproducing magnetic and optical media \\
\hline 3353 & Electrical equipment manufacturing \\
\hline 33599 & All other electrical equipment and component manufacturing \\
\hline 3361 & Motor vehicle manufacturing \\
\hline 3362 & Motor vehicle body and trailer manufacturing \\
\hline 3363 & Motor vehicle parts manufacturing \\
\hline 3364 & Aerospace product and parts manufacturing \\
\hline 3391 & Medical equipment and supplies manufacturing \\
\hline 5112 & Software publishers \\
\hline 514191 & On-line information services \\
\hline 5142 & Data processing services \\
\hline 5413 & Architectural, engineering, and related services \\
\hline 5415 & Computer systems design and related services \\
\hline 5416 & Management, scientific, and technical consulting services \\
\hline 5417 & Scientific research and development services \\
\hline 6117 & Educational support services \\
\hline
\end{tabular}


811212

Computer and office machine repair and maintenance

Source: NSF (2006). Science and Engineering Indicators. Chapter 8 State Indicators, Technical Note: Defining HighTechnology Industries. (http://www.nsf.gov/statistics/seind06/c8/c8.cfm?opt=9) accessed 11/19/2015, original list of SIC industries Hecker (1999) Table 1, pp 20.

Note: This table captures a joint effort by the Office of Technology Policy and the Census Bureau to convert the SIC codes found in Hecker (1999) to the 1997 edition of NAICS. 
APPENDIX C. HIGH TECH INDUSTRIES BY R\&D INTENSITY

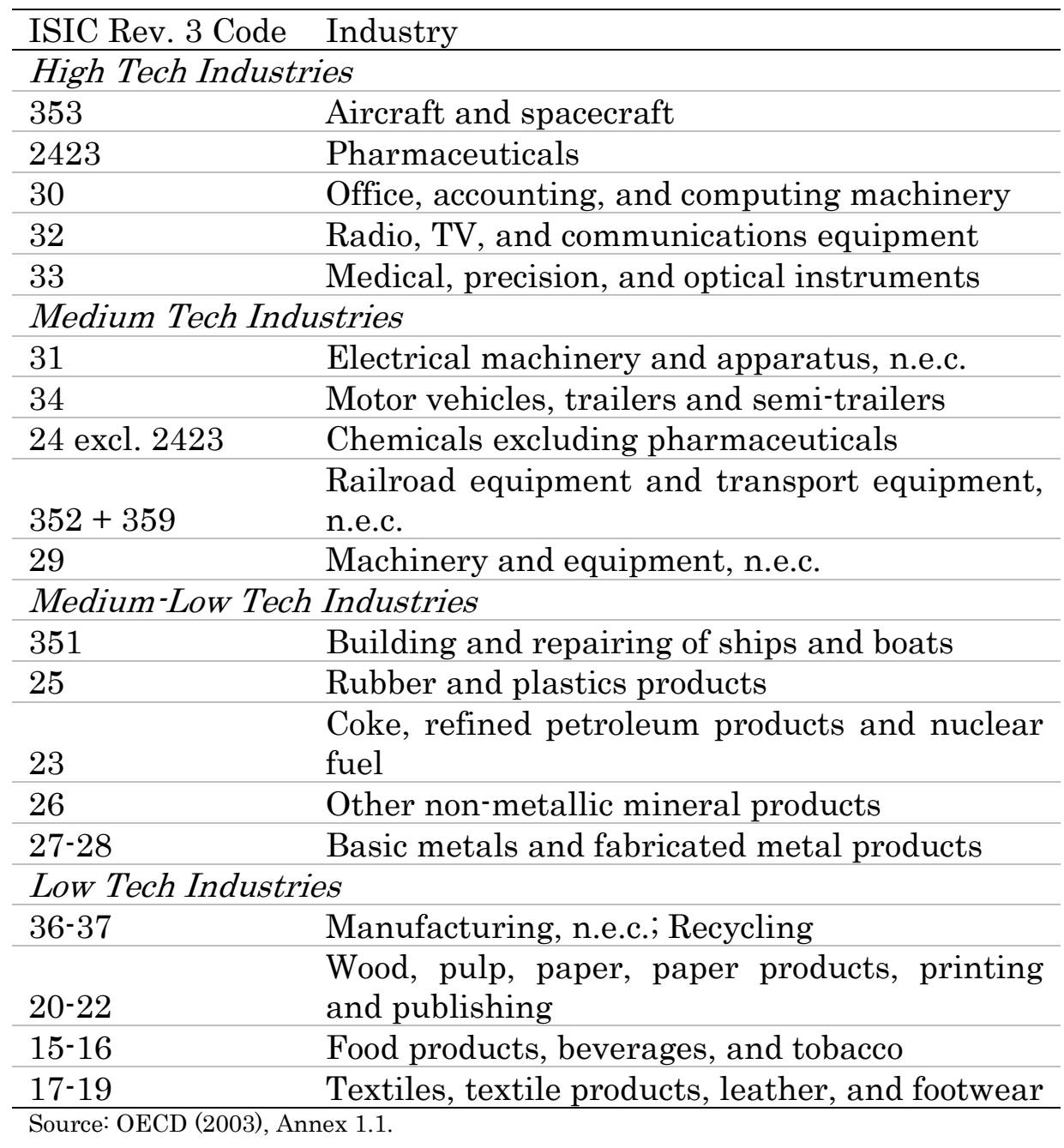


APPENDIX D. HIGH TECH INDUSTRIES - ADVANCED TECHNOLGOY PRODUCTS

\begin{tabular}{|c|c|c|}
\hline Major Tech & $\begin{array}{l}\text { NAICS } \\
(2002)\end{array}$ & Industry \\
\hline \multirow[t]{2}{*}{ Biotechnology } & 3254 & Pharmaceutical and medicine manufacturing \\
\hline & 5417 & Scientific R\&D services \\
\hline \multirow[t]{2}{*}{$\begin{array}{l}\text { Life science } \\
\text { technologies }\end{array}$} & 3345 & $\begin{array}{l}\text { Navigational, measuring, electromedical, and control } \\
\text { instrument manufacturing }\end{array}$ \\
\hline & 3254 & Pharmaceutical and medicine manufacturing \\
\hline \multirow[t]{2}{*}{ Optoelectronics } & 3341 & Computer and peripheral equipment manufacturing \\
\hline & 3344 & $\begin{array}{l}\text { Semiconductor and other electronic component } \\
\text { manufacturing }\end{array}$ \\
\hline \multirow{5}{*}{$\begin{array}{l}\text { Information and } \\
\text { communications }\end{array}$} & 3341 & Computer and peripheral equipment manufacturing \\
\hline & 3342 & Communications equipment manufacturing \\
\hline & 3345 & $\begin{array}{l}\text { Navigational, measuring, electromedical, and control } \\
\text { instrument manufacturing }\end{array}$ \\
\hline & 5112 & Software publishing \\
\hline & 5415 & Computer systems design and related services \\
\hline Electronics & 3344 & $\begin{array}{l}\text { Semiconductor and other electronic component } \\
\text { manufacturing }\end{array}$ \\
\hline \multirow{2}{*}{$\begin{array}{l}\text { Flexible } \\
\text { manufacturing }\end{array}$} & 3332 & Industrial machinery manufacturing \\
\hline & 3335 & Metalworking machinery manufacturing \\
\hline \multirow[t]{3}{*}{$\begin{array}{l}\text { Advanced } \\
\text { materials }\end{array}$} & 3344 & $\begin{array}{l}\text { Semiconductor and other electronic component } \\
\text { manufacturing }\end{array}$ \\
\hline & 3346 & $\begin{array}{l}\text { Manufacturing and reproducing magnetic and optical } \\
\text { medial }\end{array}$ \\
\hline & 3359 & Other electrical equipment and component manufacturing \\
\hline Aerospace & 3364 & Aerospace product and parts manufacturing \\
\hline Weapons & 3329 & Other fabricated metal products manufacturing \\
\hline \multirow{2}{*}{$\begin{array}{l}\text { Nuclear } \\
\text { technology }\end{array}$} & 3324 & Boiler, tank, and shipping container manufacturing \\
\hline & 3251 & Basic chemical manufacturing \\
\hline
\end{tabular}


APPENDIX E. HIGH TECH INDUSTRIES - HIGH TECHNOLOGY PRODUCTS

\begin{tabular}{ll}
\hline Sector & SITC Rev. 3 Code \\
\hline & {$\left[7921+7922+7923+7924+7925+79293+\left(714-71489^{-}\right.\right.$} \\
Aerospace & $71499)+87411]$ \\
\hline $\begin{array}{l}\text { Computers }{ }^{-o f f i c e ~} \\
\text { machines }\end{array}$ & {$[75113+75131+75132+75134+(752-7529)+75997]$} \\
\hline $\begin{array}{l}\text { Electronics- } \\
\text { telecommunications }\end{array}$ & {$[76381+76383+(764-76493-76499)$} \\
\hline Pharmacy & {$[5413+5415+5416+5421+5422]$} \\
\hline $\begin{array}{l}\text { Scientific } \\
\text { instruments }\end{array}$ & {$\left[774+8711+8713+8714+8719+87211+\left(874-87411^{-}\right.\right.$} \\
\hline Electrical & $8742)+88111+88121+88411+88419+89961+89963++89967]$ \\
machinery & {$[77862+77863+77864+77865+7787+77844]$} \\
\hline Chemistry & {$[52222+52223+52229+52269+525+57433+591]$} \\
& {$[71489+71499+71871+71877+72847+7311+73131+73135$} \\
Non-electrical & $+73144+73151+73153+73161+73165+73312+73314+73316$ \\
machinery & $+73733+73735]$ \\
\hline Armament & {$\left[891^{--}\right]$} \\
\hline Source: Hatzichronoglou $(1997)$ Table 2.
\end{tabular}




\section{APPENDIX F. INDUSTRIES LEAVING AND ENTERING HIGH TECH USING STEM METHOD}

Table 7. Industries Classified as High Tech in 2012 Only

\begin{tabular}{|c|c|}
\hline NAICS & Industry Description \\
\hline 336510 & Railroad Rolling Stock Manufacturing \\
\hline
\end{tabular}

Table 8. Industries Classified as High Tech in 2014 Only

\begin{tabular}{|c|c|}
\hline NAICS & Industry Description \\
\hline 212210 & Iron Ore Mining \\
\hline 212221 & Gold Ore Mining \\
\hline 212222 & Silver Ore Mining \\
\hline 212231 & Lead Ore and Zinc Ore Mining \\
\hline 212234 & Copper Ore and Nickel Ore Mining \\
\hline 212291 & Uranium-Radium-Vanadium Ore Mining \\
\hline 212299 & All Other Metal Ore Mining \\
\hline
\end{tabular}


APPENDIX G. HIGH TECH EMPLOYMNENT SHARE COVERAGE BY MAJOR SECTOR AND METHODOLOGY

\begin{tabular}{|c|c|c|c|c|c|c|}
\hline Major Sector & $\begin{array}{c}\text { Hecker } \\
(2005)\end{array}$ & $\begin{array}{l}\text { STEM } \\
2012\end{array}$ & $\begin{array}{l}\text { STEM } \\
2014\end{array}$ & $\begin{array}{l}\text { Census } \\
\text { ATP }\end{array}$ & $\begin{array}{l}\text { OECD } \\
(2003)\end{array}$ & $\begin{array}{l}\text { OECD } \\
(2015)\end{array}$ \\
\hline $\begin{array}{l}\text { Agriculture, Forestry, Fishing } \\
\text { and Hunting }\end{array}$ & 2.8 & 0.0 & 0.0 & 0.0 & 0.0 & 0.0 \\
\hline Arts \& Accommodation & 0.0 & 0.0 & 0.0 & 0.0 & 0.1 & 0.0 \\
\hline Construction & 0.0 & 0.0 & 0.0 & 0.0 & 0.0 & 0.0 \\
\hline Education \& Health & 0.0 & 0.0 & 0.0 & 0.0 & 6.2 & 0.0 \\
\hline FIRE & 0.2 & 16.6 & 16.6 & 0.0 & 82.0 & 0.0 \\
\hline Information & 50.0 & 52.0 & 52.0 & 12.8 & 61.4 & 13.2 \\
\hline Management \& Support & 25.7 & 24.3 & 24.3 & 0.0 & 87.4 & 0.0 \\
\hline Manufacturing & 22.7 & 22.2 & 22.0 & 19.7 & 26.2 & 47.3 \\
\hline Mining \& Utilities & 48.9 & 48.9 & 51.5 & 0.0 & 17.8 & 0.0 \\
\hline Retail \& Wholesale & 3.5 & 3.5 & 3.5 & 0.0 & 0.0 & 0.0 \\
\hline Services & 30.1 & 29.1 & 29.1 & 10.4 & 60.4 & 10.7 \\
\hline Transport \& Warehousing & 1.0 & 0.8 & 0.2 & 0.0 & 16.6 & 0.0 \\
\hline \multicolumn{7}{|c|}{$\begin{array}{l}\text { Notes: Percent of employment within major sectors covered by High Tech industries according to each methodology. } \\
\text { Employment counts are derived from } 2007 \text { count business pattern 6-digit industry level aggregates } \\
\text { (http://www.census.gov/data/datasets/2007/econ/cbp/2007-cbp.html accessed 10/17/2016). For Hecker (2005), STEM } \\
\text { 2012, and STEM 2014 show counts of industries for all three levels of High Tech intensity. For OECD (2003) we use } \\
\text { industries classified as high and medium-High Technology and for OECD (2015) we use high and medium-High } \\
\text { Technology industries. }\end{array}$} \\
\hline
\end{tabular}


APPENDIX H. HIGH TEHC INDUSTRIES - STEM UNION

\begin{tabular}{ll}
\hline NAICS & Industry Description \\
\hline 2111 & Oil and Gas Extraction \\
\hline 3254 & Pharmaceutical and Medicine Manufacturing \\
\hline 3341 & Computer and Peripheral Equipment Manufacturing \\
\hline 3342 & Communications Equipment Manufacturing \\
3344 & Semiconductor and Other Electronic Component \\
\hline & Manufacturing \\
\hline 3345 & Navigational, Measuring, Electromedical, and Control \\
\hline 3364 & Instruments Manufacturing \\
\hline 5112 & Aerospace Product and Parts Manufacturing \\
\hline 5171 & Software Publishers \\
\hline 5179 & Wired Telecommunications Carriers \\
\hline 5182 & Other Telecommunications \\
\hline 5191 & Data Processing, Hosting, and Related Services \\
\hline 5413 & Other Information Services \\
\hline 5415 & Architectural, Engineering, and Related Services \\
\hline 5417 & Computer Systems Design and Related Services \\
\hline $\begin{array}{l}\text { Source: Table lists 4-digit 2007 NAICS industries in the union of industries identified by Hecker (2005) } \\
\text { and recalculated STEM concentrations using BLS 2012 and 2014 industryoccupation employment } \\
\text { matrices. }\end{array}$
\end{tabular}

